\title{
The Hushoot Shiveetiin gol section (Baruunhuurai Terrane, Mongolia): sedimentology and facies from a Late Devonian island arc setting
}

\author{
A. Munkhjargal ${ }^{1,2} \cdot$ P. Königshof ${ }^{2}$ (D) S. Hartenfels ${ }^{3} \cdot$ U. Jansen $^{2} \cdot$ A. Nazik ${ }^{4} \cdot$ S. K. Carmichael $^{5} \cdot$ J. A. Waters ${ }^{5}$. \\ S. Gonchigdorj ${ }^{1}$ - C. Crônier ${ }^{6}$ A. Yarinpil ${ }^{7}$ - O. Paschall ${ }^{5} \cdot$ A. Dombrowski $^{5}$
}

Received: 29 April 2020 / Revised: 26 June 2020 / Accepted: 21 July 2020 / Published online: 2 November 2020

(C) The Author(s) 2020

\begin{abstract}
A Late Devonian to (?)Early Mississippian section at Hushoot Shiveetiin gol in the Baruunhuurai Terrane of the Central Asian Orogenic Belt (CAOB) exposes large parts of cyclic Famennian shallow-water siliciclastic shelf deposits composed of siltstones, sandstones, shales, volcaniclastics, and intercalated autochthonous carbonates. The youngest part of the section, possibly Early Mississippian, is represented by arkosic sandstones with large plant remains. The facies reflects a range from shallow-intertidal to outer ramp settings. In terms of conodont stratigraphy, the Hushoot Shiveetiin gol section ranges from the Palmatolepis minuta minuta Biozone to at least the Palmatolepis rugosa trachytera Biozone. Hiatuses of several conodont biozones occur due to the facies setting (erosion and reworked sediments which are recognized by reworked conodonts) rather than thrusting or folding. The environmental setting was characterized by coeval subaerial volcanism resulting in numerous pyroclastic deposits. The depositional environments and intense volcanic activity at the Hushoot Shiveetiin gol section limited the stratigraphic distribution, abundance, and diversity of many elements of the fauna such as brachiopods. Ostracods were very abundant and diverse through many parts of the section. Although limited in stratigraphic distribution, the crinoid fauna is the most diverse Palaeozoic fauna collected from Mongolia to date and supports the hypothesis that the CAOB was a biodiversity hotspot in the aftermath of the Frasnian-Famennian extinction event.
\end{abstract}

Keywords Central Asian Orogenic Belt $(\mathrm{CAOB}) \cdot$ Facies $\cdot$ Biostratigraphy $\cdot$ Volcanism $\cdot$ Biodiversity hotspot $\cdot$ Hangenberg Crisis

This is a contribution to a special series on "The Central Asian Orogenic Belt (CAOB) during Late Devonian: new insights from southern Mongolia".

A. Munkhjargal

ariuka.munkhjargal@senckenberg.de

1 Mongolian University of Science and Technology 8th khoroo, Baga toiruu 34, Sukhbaatar District, Ulaanbaatar 14191, Mongolia

2 Senckenberg Research Institute and Natural History Museum, Senckenberganlage 25, 60325 Frankfurt, Germany

3 Institute of Geology and Mineralogy, University of Cologne, Zülpicher Str. 49a, 50674 Cologne, Germany

4 Faculty of Engineering Department, Cukurova University, Mithat Özsan Bulvari, TR-01330 Adana, Turkey

5 Department of Geological and Environmental Sciences, Appalachian State University, 572 Rivers St., Boone, NC 28608, USA

6 Université de Lille, CNRS, UMR 8198 Évo-Éco-Paléo, F-59000 Lille, France

7 Section of Geology and Paleontology, Natural History Museum, P.O. Box 46/52, Ulaanbaatar 14201, Mongolia

\section{Introduction}

The global atmospheric $\mathrm{CO}_{2}$ and climate significantly changed during the mid-Palaeozoic, especially in the Late Devonian (Algeo and Scheckler 1998; Stein et al. 2007; Becker et al. 2016) and coincided with major extinction events. The most severe anoxic intervals have been documented within the Kellwasser events near the Frasnian/Famennian (F/F) boundary, the Annulata events in the Famennian, and the Hangenberg Crisis near the Famennian/Tournaisian (D/C) stage boundary (Sepkoski 1996; Racki 2005; Hartenfels 2011; Kaiser et al. 2016; Hartenfels and Becker 2016; Bond and Grasby 2017). But studies on events in the Late Devonian, particularly the $\mathrm{F} / \mathrm{F}$ boundary, primarily are focused on hemipelagic and pelagic settings (see review article by Carmichael 2019) with relatively few studies dealing with shallow-water sections. The disparity of information in different depositional settings and areas fundamentally hampers knowledge on climate change and faunal change during and 
in the aftermath of global extinction events. As a step towards addressing problems of palaeogeographic sample bias, biostratigraphy, biodiversity change in the aftermath of the $\mathrm{F} / \mathrm{F}$ events, we present results of a Famennian to (?)Early Mississippian section that ranges from shallow-subtidal to outer ramp settings within the Central Asian Orogenic Belt (CAOB).

Studies from the CAOB and neighboring regions reported high Famennian diversity from different fossil groups (Ariunchimeg et al. 2014; Zong et al. 2015; Song et al. 2017). Furthermore, bryozoans and crinoids expanding from shallow-water refugia support the idea of the CAOB as a biodiversity hotspot (Waters et al. 2003; Webster and Waters 2009; Ernst 2013; Waters et al. this issue). Recent fieldwork in the Upper Devonian deposits from the CAOB within western Mongolia (Kido et al. 2013; Ariunchimeg et al. 2014; Suttner et al. 2020) and analogous sites in NWChina (Suttner et al. 2014; Carmichael et al. 2014; Wang et al. 2016; Carmichael 2019; Song et al. 2019; Stachacz et al. 2020) suggest that the Hushoot Shiveetiin gol site in the Baruunhuurai Terrane in western Mongolia (which represents a shallow-water/neritic palaeoenvironment) is likewise essential for understanding biodiversity patterns in isolated ecosystems in the aftermath of the $\mathrm{F} / \mathrm{F}$ events.

\section{Geological setting}

The CAOB covers a huge area which extends from Kazakhstan in the west, through Kyrgyzstan, Uzbekistan, northwestern China, the Altai-Sayan region, and Transbaikalia in Russia, Mongolia, and northeastern China to the Russian Far East and includes oceanic, intra-oceanic, and numerous fragments of Precambrian microcontinents and collisional and post-collisional complexes as well as continental margin arc terranes (Xiao et al. 2010; Xiao and Santosh 2014; Yang et al. 2019). This accretionary system has evolved across at least $800 \mathrm{myr}$, from the Neoproterozoic time until the Cenozoic (Safonova et al. 2017). The complicated Palaeozoic association was formed prior to the end of the Carboniferous (Xiao et al. 2010; Metcalfe 2011; Choulet et al. 2012; Yang et al. 2013a, b; Li et al. 2017). According to Windley et al. (2007), Donskaya et al. (2013), and Yang et al. (2015), the subduction of the Palaeo-Asian Ocean continued during the mid- and late Palaeozoic before the final closure of this ocean and its Turkestan and Junggar branches during the late Palaeozoic to the Mesozoic (Safonova et al. 2017). The Palaeozoic rocks of western Mongolia described in this paper are part of the complex tectonic framework of the CAOB.

Deposits of the Baruunhuurai Terrane have a stratigraphic range from Devonian to Carboniferous and are located in the southwestern part of Mongolia close to the border to China (Badarch et al. 1998). According to earlier studies, the
Baruunhuurai Terrane is subdivided into Baaran, Ulaan-Us, and Baitag, Olonbulag subterranes (Badarch et al. 1998; Dergunov 2001). The Baaran and Olonbulag subterranes represent an Andean type active continental margin that was formed on the eastern continuation of the Caledonian Chingis Tarbagatai continent (Ruzhentsev et al. 1992). Similar tectonic structures occur in eastern Kazakhstan and northwestern China and the two proposed subterranes are analogs of the Central Kazakhstan volcanic belt. More recent studies by Tumurtogoo (2014) subdivide the Baruunhuurai Terrane into three rather than four subterranes (for a more detailed discussion on that plate tectonics, we refer to Safonova et al. 2017; an overview and description of each formation and fossil content are provided by Ariunchimeg et al. 2014).

The investigated section is located in the Olonbulag Subterrane (Fig. 1) and ranges from the Famennian to (?)Mississippian. The exposed Upper Devonian and (?)Lower Mississippian sedimentary rocks belong to the Samnuuruul Formation which has a thickness of 250$450 \mathrm{~m}$. The Samnuuruul Formation was classified for the first time during regional geological mapping (Lazarev and Suurisuren 1992). Rocks of the Samnuuruul Formation conformably lie above Middle Devonian rocks of the Khurendush Formation.

The section is primarily composed of siliciclastic rocks including volcaniclastic deposits. Limestones occur in a limited number of thin-bedded layers containing various fossils, such as corals, bryozoans, brachiopods, and conodonts, which support a Famennian age (see earlier studies by Bolshakova et al. 2003; Kido et al. 2013; Ariunchimeg et al. 2014; Suttner et al. 2020). The uppermost part of the Samnuuruul Formation consists of a series of arkosic sandstones, and conglomeratic sandstones with plant fossils, which most probably are (?)Early Mississippian in age.

\section{Materials and methods}

Forty-five samples between 1 and $4 \mathrm{~kg}$ were collected for biostratigraphic analysis from the eastern and western Hushoot Shiveetiin gol section (description of two sections are a result of different field campaigns) in order to enhance the stratigraphic record published by Suttner et al. (2020). Limestones and marls were cleaned and crushed to about $2 \mathrm{~cm}^{3}$ and placed in wide-mesh sieves hung in buckets filled with warm tap water. Formic acid was added until the dilution reached a concentration of about $5 \% \mathrm{HCOOH}$. The process was repeated until samples were dissolved. Ninety samples for conodont biostratigraphy were processed (about $93 \mathrm{~kg}$ ). The prevalence of siliciclastic sediments in the section produced very large volumes of insoluble residue in the $63-\mu \mathrm{m}$, $125-\mu \mathrm{m}, 250-\mu \mathrm{m}$, and $500-\mu \mathrm{m}$ fractions. The fractions were 


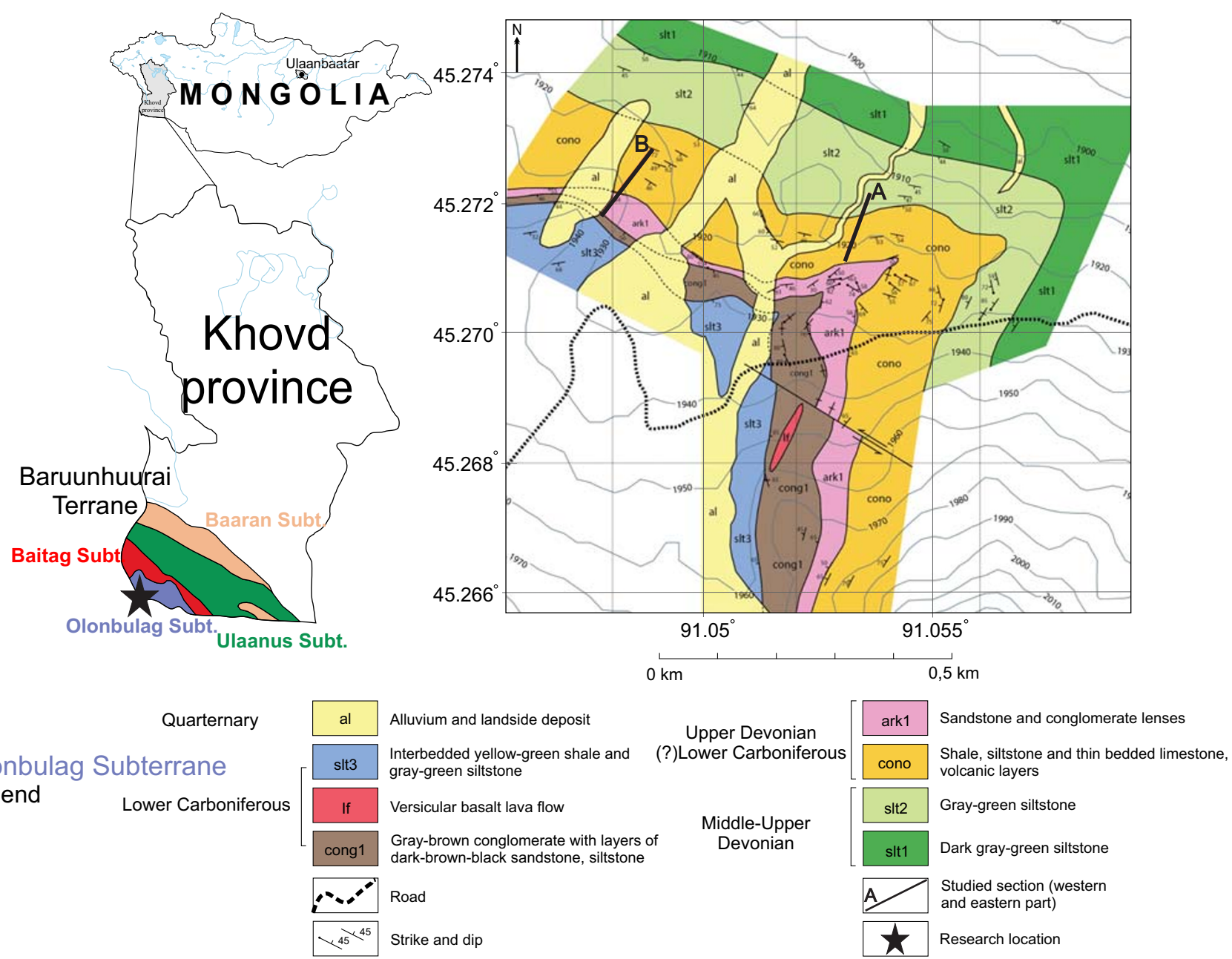

Fig. 1 Geological map of the Hushoot Shiveetiin gol section, eastern part (A) and western part (B), based on new mapping data during fieldwork in 2018

dried in an oven $\left(\sim 40^{\circ} \mathrm{C}\right)$ and the most promising conodontsized fractions were separated by using liquid sodium polytungstate. Later, the conodonts were hand-picked under a microscope. The light fractions were picked for other fossil remnants, such as microvertebrates and ostracods. Conodonts were found in a limited number of samples, but the majority of samples were barren. Nevertheless, based on new conodont data, we could improve the biostratigraphy. As it is common practice in high-resolution stratigraphic conodont studies, only Pa elements were identified, as many Upper Devonian to Mississippian multielement reconstructions are still doubtful and incomplete. All conodont samples are stored at the Research Center for Stratigraphy and Paleontology in Mongolian University of Sciences and Technology, Ulaanbaatar, Mongolia, under repository numbers MUSTRCSP-CON.0001 to 0040. Ostracods and microvertebrates are frequent in the light fractions, and thus results will be published separately.

All units were measured bed by bed at $\mathrm{cm}$ scale, and 58 rock samples were taken for microfacies analysis producing more than 100 thin sections. In order to get a thorough overview of the facies, we mainly used thin sections of 7.5 to $11 \mathrm{~cm}$ in size. The description of sandstones follows the classification published in Folk (1954), Pettijohn et al. (1973), and Tucker (2001), and is typically determined microscopically by identifying mineral composition by 300 equally spaced points across thin section. The samples were taken from all intervals of different facies. Facies and microfacies types (FT) were mainly compared on the basis of the classical models provided by Wilson (1975) and Flügel (2004). Thin sections are stored at the Senckenberg Research Institute and Natural History Museum Frankfurt, Germany, under repository numbers SMF 99299 to SMF 99349.

Selected samples were analyzed for mineral content using a Shimadzu 6000 X-ray diffraction system and Match! identification software at Appalachian State University. Mineral identification was confirmed using scanning electron microscopy with energy-dispersive Xray spectroscopy (SEM-EDS) on a JEOL JSM-IT-300LV scanning electron microscope at $25 \mathrm{kV}$ with an Oxford 
AZtecEnergy integrated silicon drift energy-dispersive Xray spectroscopy (EDS) system at Appalachian State University. Whole rock geochemical analyses were performed at Activation Laboratories in Ancaster, ON, using the Total IDENT 4E-Research analytical package.

\section{Results}

\section{Conodont biostratigraphy}

According to conodont stratigraphy, the Hushoot Shiveetiin gol section ranges from the Palmatolepis minuta minuta Biozone to at least the Palmatolepis rugosa trachytera Biozone (Fig. 2; zonation scheme follows Hartenfels 2011 and Spalletta et al. 2017). Since conodonts are scarce in siliciclastic settings, the precise age of those sediments may not be fully determinable based on conodonts only. Stratigraphic hiatuses of several conodont biozones (Palmatolepis termini, Palmatolepis marginifera marginifera, Palmatolepis marginifera utahensis, and Scaphignathus velifer velifer biozones) occur in the section because of the scarcity of index taxa and are shown in grey color in the lithological columns (see Figs. 6 and 7). As there is no evidence of thrusting in the field, we assume that this is a continuous section at least until the top of the Unit VII. The biostratigraphic hiatuses (according to the conodont record) are believed to be a result of facies (shallow-water siliciclastics); carbonates are limited to a number of single layers. Similar problems in conodont record are known from other shallowwater sections as shown for instance by Bahrami et al. (2018, 2019) and Königshof et al. (2020). Nevertheless, we could confirm the conodont data in the lower part (eastern section) published by Suttner et al. (2020) and improve the biostratigraphy for the entire section (Figure 3).

Now seven conodont biozones were indicated by either the first occurrence (FO) or the presence of some distinct taxa. In order to avoid doubling of already published data by Suttner et al. (2020), we mainly figure new taxa and taxa found in the western section. The conodont biozones of the Hushoot Shiveetiin gol section are as follows:

(a) Palmatolepis minuta minuta Biozone: based on the presence of Palmatolepis minuta minuta in sample HS-cono16 (Suttner et al. 2020)

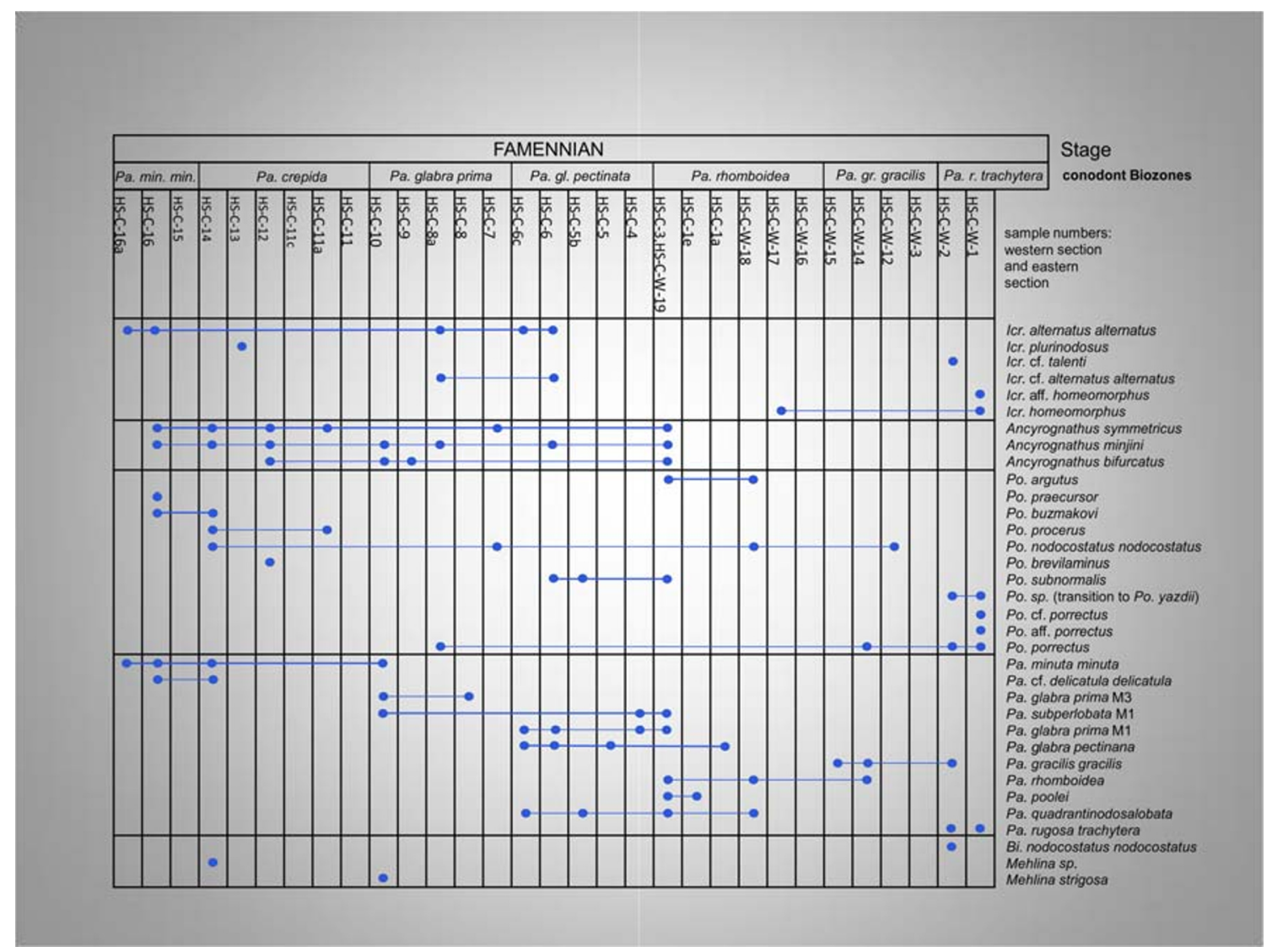

Fig. 2 Conodont distribution chart of Famennian deposits at the Hushoot Shiveetiin gol section. Data compiled from Suttner et al. (2020) and data from fieldwork in 2018 presented herein. Zonation scheme follows Spalletta et al. (2017) 

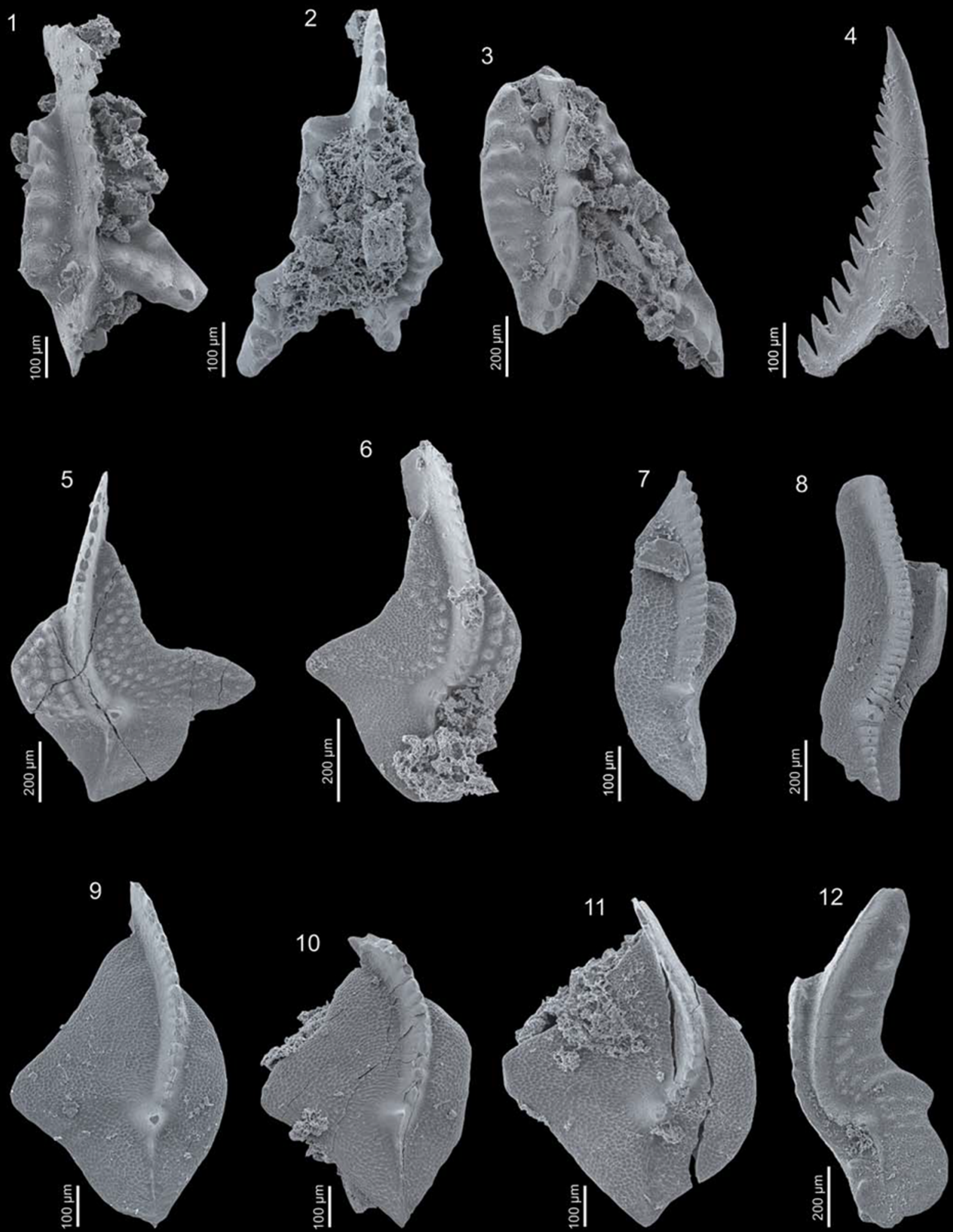
Fig. 3 Important conodonts from the Hushoot Shiveetiin gol section (collection numbers in brackets). 1: Ancyrognathus symmetricus, sample HS-C-W-19, oral view (MUST-RCSP-CON. 0003); 2: Ancyrognathus minjini, sample HS-C-3, oral view (MUST-RCSPCON. 0004); 3: Ancyrognathus bifurcatus, sample HS-C-9, oral view (MUST-RCSP-CON. 0012); 4: Caenodontus sp., sample HS-C-6c (MUST-RCSP-CON.0033); 5: Palmatolepis cf. quadrantinodosalobata (atypical morphotype) sample HS-C-6c, upper view (MUST-RCSPCON.0034); 6: Palmatolepis quadrantinodosalobata sample HS-C-W18, upper view (MUST-RCSP-CON. 0021); 7: Palmatolepis glabra prima M3, sample HS-C-10, upper view (MUST-RCSP-CON. 0014); 8: Palmatolepis glabra pectinata M2, sample HS-C-6c, upper view (MUST-RCSP-CON. 0020); 9: Palmatolepis sp., transitional form between Palmatolepis subperlobata and Palmatolepis delicatula delicatula, sample HS-C-W19, reworked conodont, upper view (MUST-RCSPCON. 0035); 10: Palmatolepis delicatula platys, reworked conodont, sample HS-C-W4, upper view (MUST-RCSP-CON. 0036); 11: Palmatolepis delicatula platys, reworked conodont, sample HS-C-W18 (MUST-RCSP-CON. 0023); 12: Palmatolepis rugosa trachytera, sample HS-C-W-2, upper view (MUST-RCSP-CON.0028)

(b) Palmatolepis crepida Biozone: based on the presence of Polygnathus nodocostatus nodocostatus in sample HScono-14 (Suttner et al. 2020)

(c) Palmatolepis glabra prima Biozone: based on FO of Palmatolepis glabra prima in sample HS-cono-10

(d) Palmatolepis glabra pectinata Biozone: based on FO of Palmatolepis glabra pectinata M2 in sample HS-C-6c

(e) Palmatolepis rhomboidea Biozone: based on FO of Palmatolepis rhomboidea in sample HS-cono-3 (Suttner et al. 2020)

(f) Palmatolepis gracilis gracilis Biozone: based on FO of Palmatolepis gracilis gracilis in sample HS-C-W15

(g) Palmatolepis rugosa trachytera Biozone: based on FO of Palmatolepis rugosa trachytera in sample HS-C-W2

Conodonts in general are not very well preserved. Many conodonts are broken, some species show abrasion features as a result of sediment transport, and sediment is often attached to the surfaces of elements. Conodont color alteration (CAI, Epstein et al. 1977) has a range between 3 and 4. Although carbonate samples of 1 to $4 \mathrm{~kg}$ per sample were dissolved for biostratigraphic analysis, the overall number of conodont elements is relatively low. Even so, the high diversity of polygnathid species during the Palmatolepis crepida Biozone and of palmatolepids during the Palmatolepis rhomboidea Biozone recognized by Suttner et al. (2020) can be confirmed in this study. Conodont taxa are dominated by polygnathid-palmatolepid associations, whereas species of Icriodus, Ancyrognathus and Mehlina occur in a subordinate number.

The Palmatolepis rugosa trachytera Biozone, which is the youngest zone in our succession, is defined by the first occurrence of the name-giving taxon in sample HS-C-W2. Polygnathus porrectus (see Fig. 4: 6-8) occurs in this sample as well as in the next younger sample (sample HS-C-W1). Our results support the proposed stratigraphical range by Barskov et al. (1991) who suggested a range from the rhomboidea to the trachytera biozones (zonal scheme of Ziegler and Sandberg 1984). Due to the facies setting (see below), some conodonts were reworked. Icriodus homeomorphus (Fig. 4: 14) occurs in samples HS-C-W1 (Palmatolepis rugosa trachytera Biozone) and an incomplete form was found in HS-C-W17 (Palmatolepis rhomboidea Biozone). In both biozones, this taxon normally does not occur. According to Mawson in Talent and Mawson (1999), it cannot be older than Late triangularis (= Palmatolepis minuta minuta, Spalletta et al. 2017) Biozone and occurs with Icriodus alternatus mawsonae in KUR 21 and 22, a form argued by Yazdi (1999) to range from Late triangularis Biozone to Early crepida (= Palmatolepis crepida, Spalletta et al. 2017) Biozone. Also, other species have been reworked such as Palmatolepis delicatula platys which were found in sample HS-C-4. Polygnathus sp. occurs in the uppermost part of the section in sample HS-C-W1. This species shows an affinity to Polygnathus yazdii based on the inner platform half. In sample HS-C-W2, an Icriodus species was found which looks like Icriodus talenti. Based on the limited number of specimens, we describe that as Icriodus cf. talenti. Ashouri (2006) described this species from the postera zones. However, Wang et al. (2016) described specimens from the local Polygnathus pomeranicus Biozone to basal Polygnathus pseudocommunis Biozone (= roughly Palmatolepis glabra pectinata to Palmatolepis marginifera marginifera biozones) from the Wulankeshun section, (Junggar Basin, China). It seems that this species has a long stratigraphical range but further research is necessary. In the uppermost part of the section, no conodonts were found due to unsuitable facies (siltstones, sandstones, conglomerates).

\section{Other fauna}

\section{Ostracods}

The Frasnian-Famennian (F/F) Kellwasser events resulted in the extinction of nearly $75 \%$ of marine ostracod taxa, mostly neritic or pelagic forms, whereas the deep-water Thuringian Mega-Assemblage (TMA) was relatively unaffected (e.g. Crasquin and Horne 2018). A large number of ostracod shells (complete ones as well as isolated ones) were preserved in the residues (light fraction) for conodont preparation. Thirteen of the studied 45 samples contain ostracod specimens as single valves and carapaces. Due to an early diagenetic silicification (see the "Sedimentology and facies" section and the following), ostracod carapaces are mainly complete and show excellently preserved carapace surface sculptures (Fig. 5, Nazik et al. this issue). 


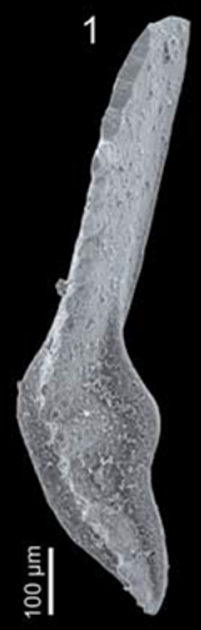

2

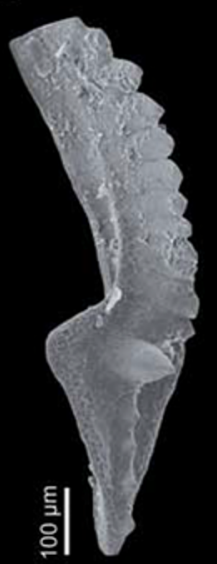

6

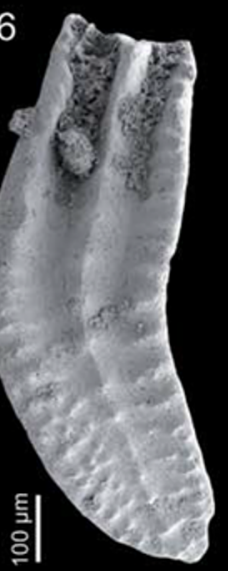

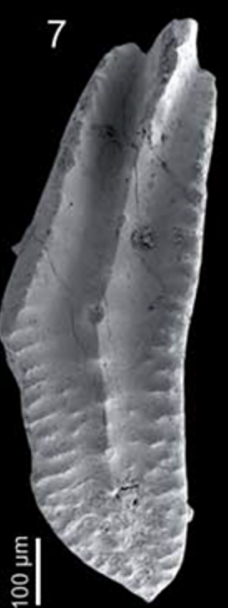

8

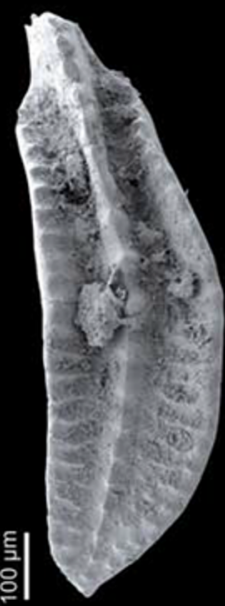

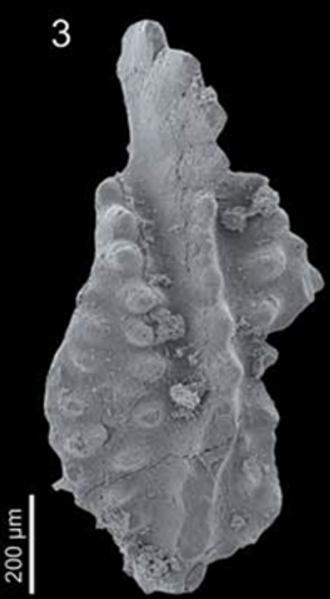
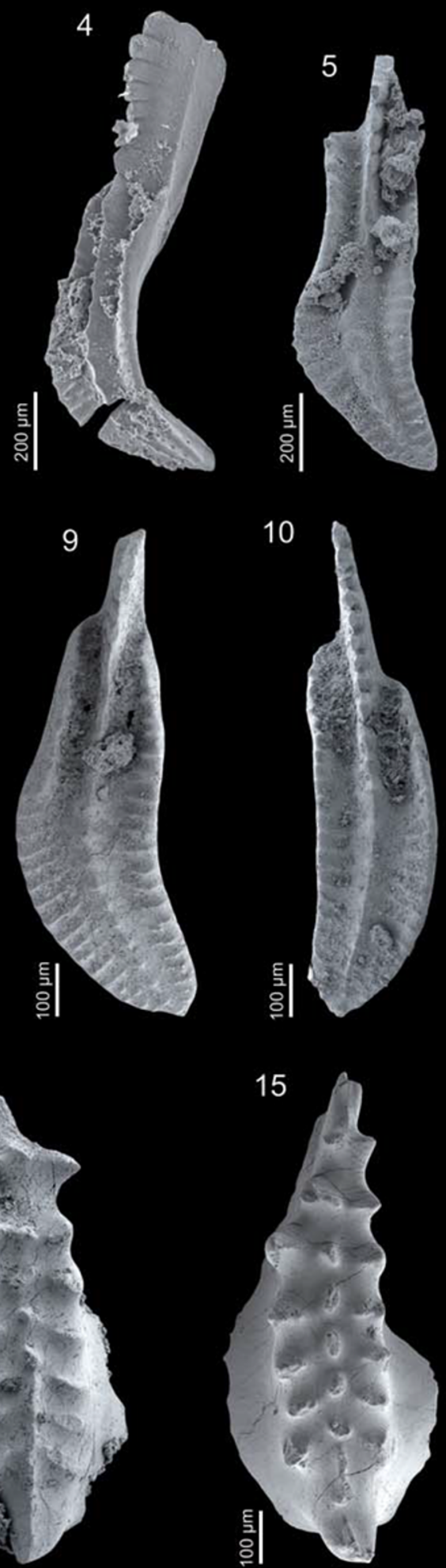

14

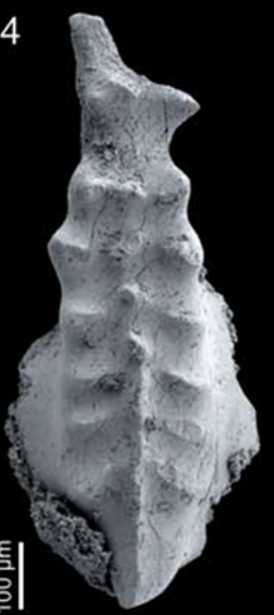

11

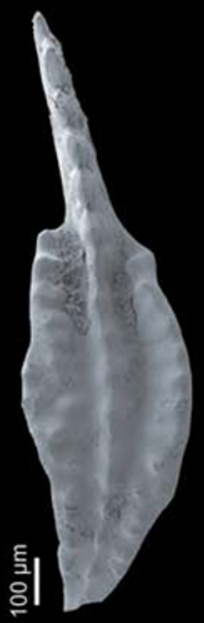

12

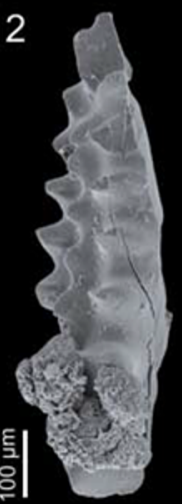

13

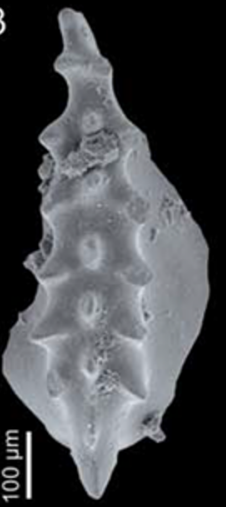


4 Fig. 4 Important conodonts from the Hushoot Shiveetiin gol section. 1: Palmatolepis gracilis gracilis, sample HS-C-W-15, upper view (MUSTRCSP-CON. 0026); 2: Palmatolepis gracilis gracilis, sample HS-C-W2, upper view (MUST-RCSP-CON. 0026); 3: Ancyrognathus sp. sample HS-C-5b (MUST-RCSP-CON. 0037); 4: Polygnathus subnormalis, broken specimen, sample HS-C-6 (MUST-RCSP-CON. 0022); 5: Polygnathus argutus, sample HS-C-W19 upper view (MUST-RCSPCON. 0038); 6, 7, 8: Polygnathus porrectus, sample HS-C-W1, upper view (MUST-RCSP-CON. 0018); 9: Polygnathus cf. porrectus, sample HS-C-W1, upper view (MUST-RCSP-CON. 0031); 10: Polygnathus aff. porrectus, sample HS-C-W1, upper view (MUST-RCSP-CON. 0032); 11: Polygnathus sp., sample HS-C-W1, upper view (MUST-RCSPCON. 0027); 12: Icriodus cf. alternatus alternatus, sample HS-C-6 (MUST-RCSP-CON. 0017); 13: Icriodus cf. talenti, sample HS-C-W2 (MUST-RCSP-CON.0001); 14: Icriodus homeomorphus, sample HS-CW1, upper view, reworked conodont (MUST-RCSP-CON.0025); 15: Icriodus aff. homeomorphus, sample HS-C-W1, upper view (MUSTRCSP-CON.0030), reworked conodont (explanations in the text)

palaeocopid, platycopid, and podocopid groups of ostracods in one single sample. The overall ostracod fauna is widespread and diverse. The fauna shows affinities to known species from Europe, Russia, and to the Hongguleleng Formation, western Junggar Basin in China (Song and Gong 2019; Nazik et al. this issue), but endemic species and new species occur as well (Nazik et al. this issue). Generally, the ostracod assemblages found in the Hushoot Shiveetiin gol section are ecologically equivalent to the Eifelian Mega-Assemblage (I-III) which represents an overall nearshore palaeoenvironment. Ostracods are valuable proxies for palaeoecological interpretations and palaeoenvironmental conditions supporting the sedimentology and facies interpretation herein. Lethiers and Casier (1996) suggested that Famennian ostracods in the aftermath of the F/F extinction established from oxygen oases in shallow waters without reefs or mud mounds. In comparison to our studied section, it seems likely that diverse ostracod assemblages expanded from shallow-water refugia what would support the hypothesis from these authors. Due to the large number of

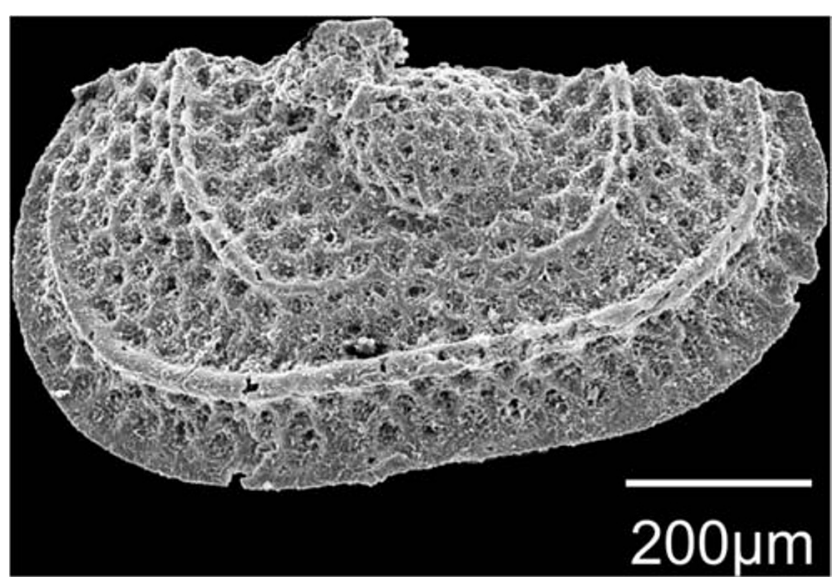

Fig. 5 Amphissites centrocostatus Blumenstengel 1969 (1969 (left valve, MUST-RCSP-Ost.00007), from the Palmatolepis rugosa trachytera Biozone of Unit VII, sample HS-C-W1). Note the well-preserved carapace surface sculpture different species, a detailed description and a discussion of palaeogeographic affinities will be published separately (Nazik et al. this issue).

\section{Bryozoa}

The diversity of Devonian bryozoans displays a persistent rise from the Pragian to the early Givetian, before dropping significantly in the late Givetian as a result of the Taghanic Event. Bryozoans experienced a slight decline during the F/ F events, beginning their recovery during the middle Famennian (Ernst 2013 cum lit.). Based on results published by Ariunchimeg (2000), bryozoans found in the Samnuuruul Formation were correlative with the Simorinski horizon in Kazakhstan, the Late Famennian in the Rudny Altai, the Middle crepida (= Palmatolepis termini) Biozone in northwestern China, and the Etroeungtian of Western Europe. Overall, the Samnuuruul Formation yielded numerous dendroid, encrusting and fenestrate colonies of 12 species and 11 genera (Ariunchimeg 2000).

\section{Brachiopods}

The Devonian was a time of high diversity of the Phylum Brachiopoda with the maximum of Phanerozoic diversity in the Emsian (Curry and Brunton 2007). The phylum was much affected by the Middle and Late Devonian extinction events such as the Choteč and Taghanic events, and in particular the Kellwasser events at the Frasnian/Famennian boundary (Walliser 1996). Before the Famennian, all stocks of the Pentamerida, Orthoidea, Atrypida, the "stropheodontoid" Strophomenida, most delthyridoid spiriferids, and many other groups went extinct (Copper 1998; Brice et al. 2000). None of these occur in the Hushoot Shiveetiin gol section. In the Famennian, spiriferids along with rhynchonellids, productids, athyridids, and some orthids are the most common groups, and this applies to this section as well. The preservation of the material is not very good but allows some preliminary statements:

The most abundant group throughout the section are the Spiriferida. The assemblages of several units (HS-F1, 3-7, 10, 13-17; HS-WS 30) contain a conspicuous, coarsely ribbed mucrospiriferine; the subfamily is restricted to the Middle and Late Devonian. The specimens, partly occurring in abundance (HS-F14), belong to a possibly undescribed genus characterized by extended, mucronate cardinal extremities, particularly strong sulcus-bounding costae on the ventral valve and deep corresponding furrows on the dorsal valve; the form resembles representatives of the Givetian-Frasnian genus Eleutherokomma. A possibly different species shows a medially depressed dorsal fold (in HS-F $15+16$ ). Cyrtospiriferids are a second group; the specimens from HS-WS 30 and HS-F 11 
are preliminarily identified from external characters as Validospirifer vel Cyrtospirifer sp.

Numerous specimens of a unisulcate, costellate dalmanelloid (from levels HS-F1, 4, 5, 8, 10, 17) are identified as ?Aulacella sp., a second form with large, flabellate ventral muscle field (HS-F6, 9-11) may belong to Rhipidomella. Identified on the genus level, both forms are stratigraphically insignificant. The strophomenoid genus Leptagonia has a Devonian-Early Carboniferous range; a still unidentifiable species occurs in HS-F $5+10$. A productellid with coarse spines on the ventral valve (Productella sp.?) occurs at a number of levels (HS-F7, 10, 13, 17, 18), moreover a larger, shield-shaped productid (HS-F14 +18) and small chonetoids (HS-F15 +16). Smooth, lenticular forms, possibly athyridids, are present at several levels (HSF6, 8, 10, 19, HS-WS-27). A few strongly plicate rhynchonellids (HS-F6, 7, 10, 12, 17) are present but too poorly preserved as to allow an identification.

In summary, the brachiopod assemblages show a relatively low to moderate diversity pointing to somewhat restricted conditions of a shallow-water palaeoenvironment. Its overall character fits a Famennian age; the mucrospiriferine species is a late representative of its subfamily.

\section{Echinoderms}

Crinoids and blastoids from the Samnuuruul Formation are the most diverse and most abundant Palaeozoic echinoderm fauna known from Mongolia. The fauna consists of 12 genera of crinoids - 4 genera of camerates, 3 genera of flexibles, one disparid genus, and 4 genera of cladids. We also have identified two genera of blastoids, the first occurrence of the class in Mongolia. The echinoderms were collected from a relatively narrow stratigraphic interval in Unit IV in the western section in the Palmatolepis rhomboidea Biozone. Taxonomic details of the echinoderm fauna are published in Waters et al. (this issue).

The fauna is comparable to the coeval echinoderm fauna from the Hongguleleng Formation in Xinjiang Uyghur Autonomous Province, China (Lane et al. 1997; Waters et al. 2003; Webster and Waters 2009); the fauna supports the hypothesis that the CAOB was a diversity hotspot for Famennian echinoderms and a precursor to the very successful echinoderm communities that dominated Mississippian shallow marine ecosystems globally (Waters et al. this issue).

\section{Trilobites}

Trilobites were relatively abundant and diverse in marine Devonian habitats. In particular, the Late Devonian epoch is important for the development of Phacopidae because the main groups of reduced-eyed or blind phacopids arose at that time (Crônier et al. 2013). During Late Devonian time, eustatic variations (transgressive-regressive pulses) had a major influence on the phacopid diversity and their evolution leading to major bioevents such as the upper Kellwasser Event and the Hangenberg Crisis (Crônier et al. 2013). At the global scale, the Kellwasser events led to the extinction of almost all reefs and their associated trilobites (Lichidae), and a significant decrease in other trilobite taxa. The Kellwasser extinction especially affected phacopids adapted to life in deep benthic habitats and their biodiversity, and led to a turnover (Lerosey-Aubril and Feist 2012; Crônier et al. 2013). During the Famennian, trilobite diversity was punctuated by several bioevents (Crônier et al. 2013). In the late part of the Early Famennian, the significant post-Kellwasser event recovery marked a new step especially for phacopid trilobites with new blind phacopid genera from deep offshore habitats and eyed-phacopid genera from shallower habitats in the photic zone (Crônier et al. 2013; Feist 2019).

Excluding the Americas, Famennian phacopids are characterized by a worldwide distribution (Chlupáč 1975; Crônier and François 2014; Feist 2019). However, if the majority of genera is apparently limited to a single cratonic margin, the other few genera are cosmopolitan (Crônier and François 2014). New discoveries in unexploited areas such as the newly studied western Mongolia once again reveal the endemic nature of many genera. The studied material (Crônier et al. this issue) comes from one section, i.e. Hushoot Shiveetiin gol section, in three levels (levels HS-cono 1, 3, and 5 and 13) rich in diverse conodonts (Suttner et al. 2020) and macrofossils including brachiopods, solitary rugose corals, and branching tabulate corals. According to two endemic and few cosmopolitan conodont taxa found in this section, our trilobite samples range from the Palmatolepis crepida to the Palmatolepis rhomboidea biozones in the Early Famennian. The studied material is most often incomplete, difficult to prepare, and often preserved as an internal mold. Due to insufficient preservation of the cephalon and the pygidia, additional material is required. However, the only relatively wellpreserved phacopid trilobite is assigned to a new genus (Crônier et al. this issue), thus becoming an endemic taxon from western Mongolia on account of the cephalic shape and doublure.

\section{Sedimentology and facies}

The Hushoot Shiveetiin gol section is divided into an eastern part and a western part (Fig. 1). Both sections can be correlated based on a pyroclastic marker horizon (HS-S-11, see Figs. 6 and 7) which occurs in the uppermost part of the eastern section and marks the beginning of the western section at the base. The distance between both sections is approximately $350 \mathrm{~m}$. Correlation is also proven by conodont data (see 
conodont zonation in each lithological log-left column). In the following description of different units, we summarize both sections. The Hushoot Shiveetiin gol section has a thickness of $148.50 \mathrm{~m}$ and is characterized by shallow-shelf mixed siliciclastic/carbonate facies and frequently intercalated volcani-clastic rocks. Geochemical analysis of the volcaniclastic units all suggest an island arc volcanic sediment source (Fig. 8), consistent with the tectonic interpretations of the region. Microfacies analysis allowed the discrimination of eight microfacies types (FT), which are described from shallowest to deepest palaeoenvironment. The Hushoot Shiveetiin gol section is of Famennian to (?)Early Mississippian age and ranges from the Palmatolepis minuta minuta Biozone to at least the Palmatolepis rugosa trachytera Biozone (biozonation follows Hartenfels 2011 and Spalletta et al. 2017). Unfortunately, the exposed, possible Lower Carboniferous rocks do not contain conodonts. The arkosic sandstones contain some plant remains which are less useful for very detailed stratigraphy but most probably belong to the (?)Lower Mississippian.

Lithological units of the Hushoot Shiveetiin gol section

The Hushoot Shiveetiin gol section is subdivided into eight lithological units which are described from the base of the section (N $\left.45^{\circ} 16^{\prime} 19.4^{\prime \prime}, \mathrm{E} 91^{\circ} 02^{\prime} 13.0^{\prime \prime}\right)$ to the top ( $45^{\circ}$ $16^{\prime} 19.8^{\prime \prime}$, E $91^{\circ} 02^{\prime} 53.2^{\prime \prime}$ ). Unit I is mainly composed of siltstones in the lower part and siltstones and greenish shales in the upper part. Occasionally thin-bedded limestones and/or limestone lenses which are intercalated in siltstones occur. Some limestones yielded conodonts of Palmatolepis minuta minuta Biozone and Palmatolepis crepida Biozone (Fig. 6). In distinct layers, brachiopods, crinoids, and trilobites occur in descending order. A limited number of thin-bedded volcanic ashes occur in the lower and middle parts of this unit which has a thickness of $18 \mathrm{~m}$.

Unit II has a thickness of $19.5 \mathrm{~m}$ and is mainly composed of greenish shales. Intercalated are thin-bedded siltstones and limestones. Some of these limestones are fossiliferous yielding conodonts, brachiopods, crinoids, and bryozoans. Two layers of several-centimeter-thick ash beds occur in that unit. Youngest sediments of this unit belong to the Palmatolepis glabra prima Biozone. In contrast to the latter unit, Unit III exhibits a change from greenish shales to more greyish shales. Intercalations of thin-bedded limestones and marly limestones occur but most of them are barren. Within the base of this unit, the transition from the Palmatolepis glabra prima Biozone to Palmatolepis glabra pectinata Biozone could be determined. Unit III has a thickness of $19.9 \mathrm{~m}$.

Rocks of Unit IV occur in the eastern and the western sections. The rock sample HS-S-11 (pyroclastic ash) is the marker horizon, which occurs in both sections. In this unit, several lithological changes exist. The lower part is dominated by greenish shales, a number of volcanic ashes, and several fossiliferous limestones. Ash layers can reach a remarkable thickness of several decimeters to meters. Directly above the marker horizon, conodonts of the Palmatolepis rhomboidea Biozone were found in limestone nodules in both sections. Thus, the sections can be correlated by both lithology and biostratigraphy. Underlying sediments belong to the next older Palmatolepis glabra pectinata Biozone. In the upper part of this unit, more carbonate layers occur, intercalated in greenish shales, whereas ash layers become rare. Particularly, this part of the section shows cyclic sedimentation, a feature which is well known from other Famennian sections in shallow water as well as in hemipelagic facies (e.g. Hartenfels 2011; Hartenfels and Becker 2016). The rhythmite-bearing succession which might be associated with 405-kyr and 100-kyr eccentricity cycles (De Vleeschouwer, personal communication) may be linked with astronomical rhythms in Late Devonian sedimentary successions (e.g. De Vleeschouwer et al. 2013). In the uppermost part of this unit, conodonts of the next younger Palmatolepis gracilis gracilis Biozone were found. Unit IV has a thickness of $30.5 \mathrm{~m}$.

Unit $\mathrm{V}$ is composed of greenish shales with few intercalations of limestones and pyroclastic rocks. Generally, the thin carbonate layers are less fossiliferous; only some of them contain brachiopods. The thickness is $13 \mathrm{~m}$. The overlying Unit VI is characterized by the occurrence of greenish, nonfossiliferous shales, ash layers, and rare brownish shales and limestones. In the lower part, a remarkable thick-bedded shale with significant volcanic components of several meters thickness occurs. In the middle part, a thick-bedded fossiliferous limestone occurs, which is mainly composed of bryozoans. The entire unit has a thickness of $31 \mathrm{~m}$. Due to the facies setting, no conodonts or macrofossils were found, and no biostratigraphic data for the interval of the Unit $\mathrm{V}$ and Unit VI are available. In terms of conodont biostratigraphy, we have a hiatus ranging from the Palmatolepis marginifera marginifera Biozone at least to the Scaphignathus velifer velifer Biozone because the conformably overlying unit yielded conodonts of the next younger Palmatolepis rugosa trachytera Biozone. As there is no visible break in sedimentation we assume that this succession represents a continuous sedimentary record.

Unit VII shows a rather variable rock record in comparison to the previous units as this unit is composed of brownish and greenish shales, siltstones, sandstones, volcaniclastic sediments as well as fossiliferous limestones in the upper part where conodonts were found (Fig. 7). A precise biostratigraphic datum (Palmatolepis rugosa trachytera Biozone) comes from the youngest limestones found in the Hushoot Shiveetiin gol section. This unit has a thickness of $15.4 \mathrm{~m}$.

The overlying Unit VIII with an overall thickness of $11.1 \mathrm{~m}$ begins with the first thick-bedded sandstones, brownish 


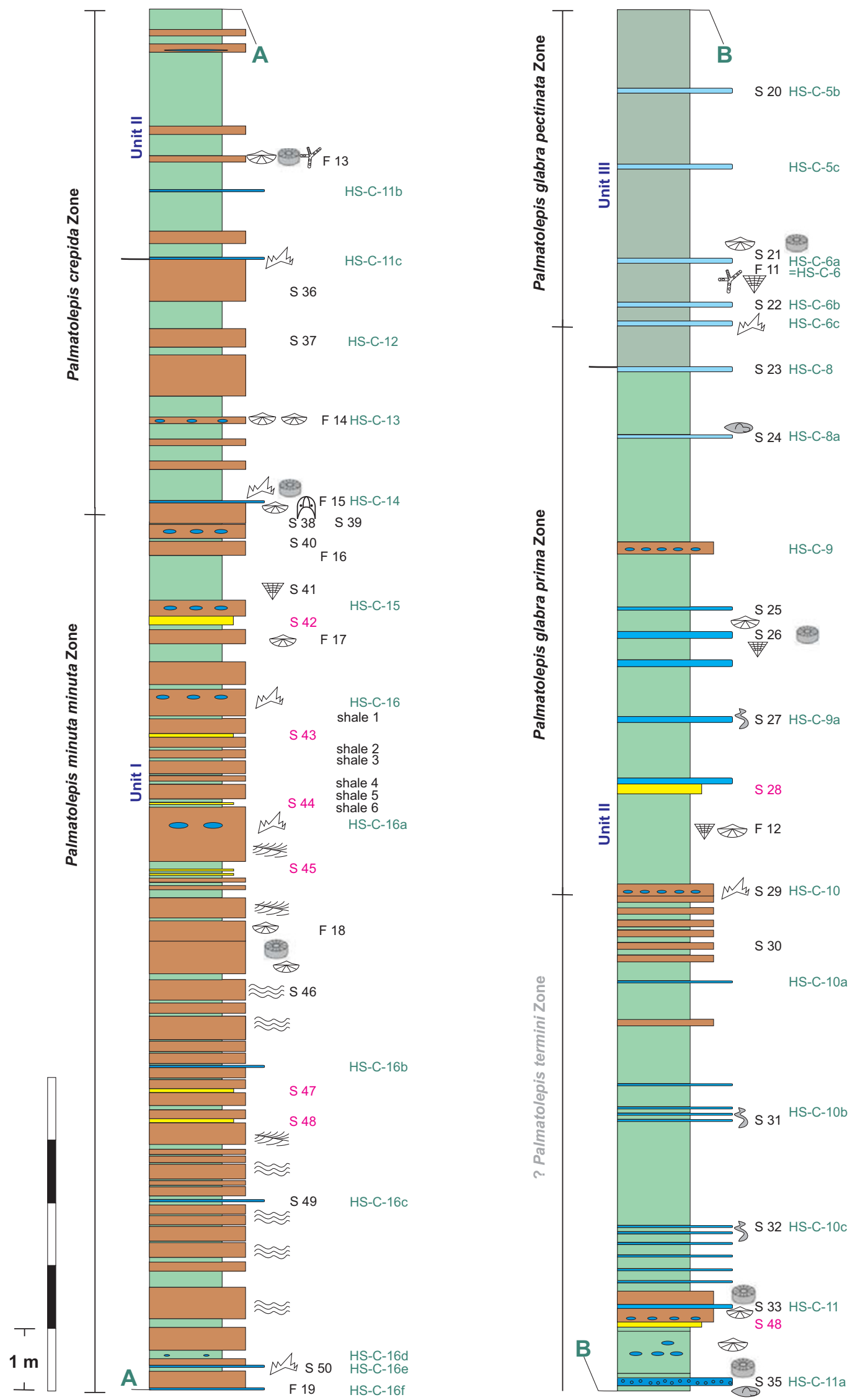

N $45^{\circ} 16^{`} 19.4^{\prime \prime}$ E $91^{\circ} 03^{`} 13.0^{\prime \prime}$ Base of the Hushoot Shiveetin Gol section (eastern part) 


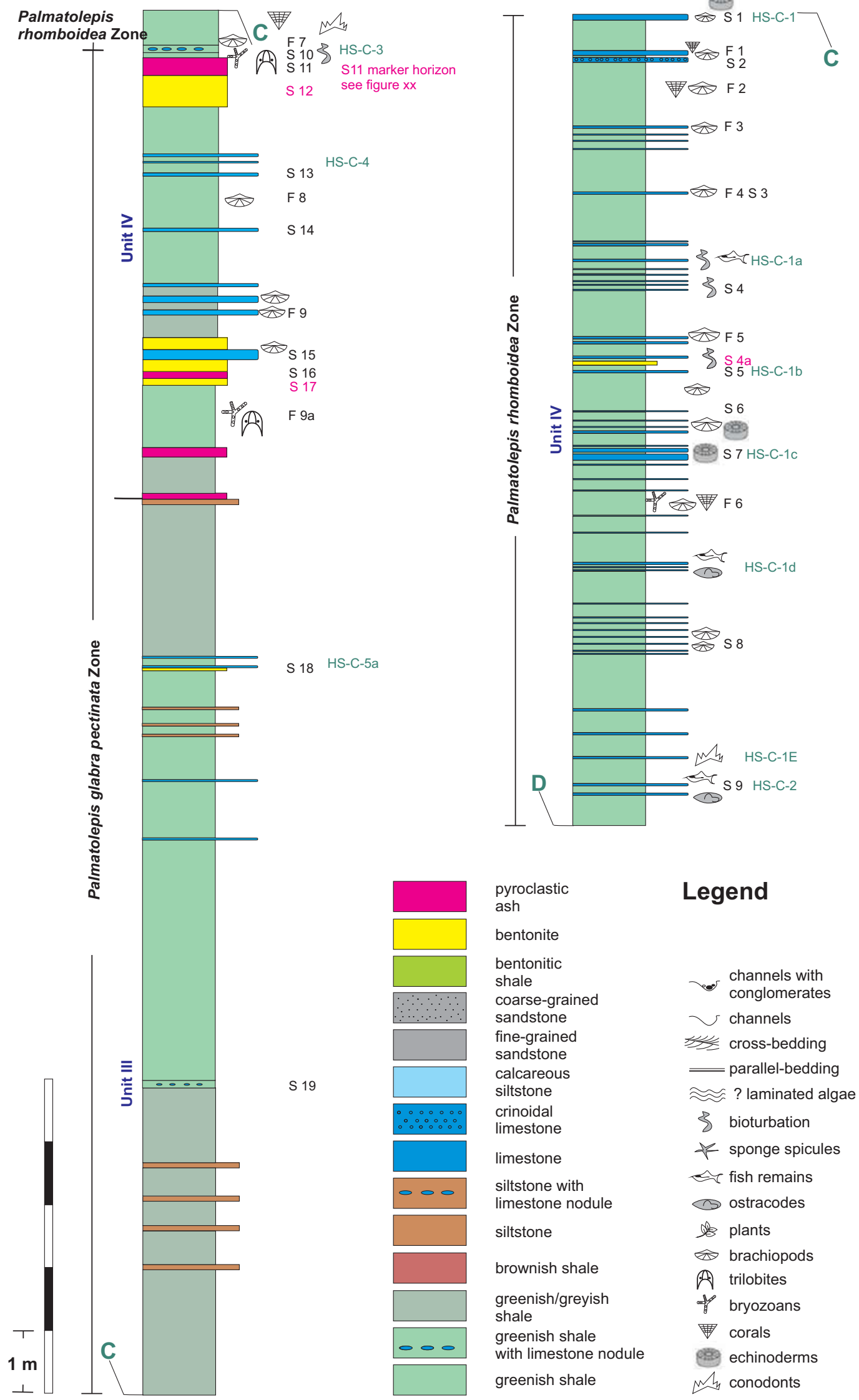

Fig. 6 (continued) 
Fig. 6 Lithological $\log$ and conodont stratigraphy of the Hushoot Shiveetiin Gol section (eastern part). The pyroclastic ash layer (rock sample S11) is a marker horizon which links the eastern and the western part (= rock sample WS-S-11 of the section) part of the section). The left column shows the conodont biozones. Conodont biozones shown in black color are clearly indicated by either first appearance (FAD) or the presence of distinct taxa (including data from Suttner et al. 2020); insufficient data or no conodont data are marked with a "?" and are shown in grey color (further explanation in the text). The lithological log is subdivided into sedimentological units (Unit I to Unit IV). Abbreviations: for example "S 19"-sedimentology/facies sample, sample numbers shown in pink were taken for geochemistry; "shale 1"sample for geochemistry; "HS-C-1c" — conodont sample (the samples which were taken in an earlier field campaign in 2014 - see Suttner et al. (2020) are also included in this log; samples from the western part were taken in 2018); "F 9"- -sample taken for macrofauna. The legend shown in this figure is also valid for the lithological log of the western section-see Fig. 7)

shales, and thin-bedded sandstones, which are covered by thick-bedded sandstones showing sedimentary structures such as parallel bedding and cross bedding. The top of the Samnuuruul Formation at Hushoot Shiveetiin gol is composed of thick-bedded coarse-grained sandstones and conglomerates (Fig. 7) with macroscopic plant debris (Fig. 9). Similar successions are known from other sections in the vicinity (Kido et al. 2013) and may represent sediments of the Lower Carboniferous.

\section{Facies}

Samples for facies analysis were taken wherever distinctive facies differences were observed in the field. The overall facies setting ranges from shallow intertidal to open marine (mid- to outer ramp setting). In some diagnostic layers, a further subdivision into sub-environments, such as lagoonal setting, is possible. Lithological/facies differences at Hushoot Shiveetiin gol likely record a series of sea-level changes in the overall shallow-water sequence. A very common feature of the section is early diagenetic silicification, which is linked to the occurrence of sponge spicules providing the source of silica (e.g. Tucker and Wright 1990; Gimenez-Montsant et al. 1999).

We recognized eight facies types (FT, including subfacies types) which are described and interpreted below from the shallowest to the deepest palaeoenvironmental setting.

\section{FT 1: arkosic sandstone}

This facies is limited to the youngest part of the section and is composed of medium to thick-bedded arkosic sandstones. The clasts, which are mainly fine- to medium-grained (also coarsegrained layers occur), are composed of quartz, feldspar (albite), varying amounts of other minerals, and rare lithic clasts, such as volcanic fragments. The sandstones contain less than
$14 \%$ matrix. They exhibit alternations of cross-bedding and planar bedding. The internal structure of the latter bedding type is characterized by parallel, sometimes slightly wavy, sandy layers, several millimeters thick, sometimes showing gradation (fining-up; Fig. 10a, sample WS-S-4/2). Ripple marks of both current and wave origins can be found. In distinct layers, reworked well-rounded lithoclasts (mud-pebbles) occur. Lamination is also a common feature and associated with peloidal laminae, iron oxide grains, and small shell hash (Fig. 10b, sample WS-S-5). Bioturbation has not been found. The uppermost part of the section contains plant fossils (Fig. 9) which point to an Early Carboniferous age. These rocks are also recorded in other sections in western Mongolia (Kido et al. 2013).

Interpretation: The overall facies points to a shallow-marine, intertidal to subtidal facies setting which is supported by channel lag deposits, and current and wave ripples. The horizontal bedding in fine-grained sandstone reflects deposition under hydrodynamic conditions of the upper flow regime (upper plane bed). The sandstones are perhaps deposited as a series of coastal barrier bars in a shallow-subtidal palaeoenvironment. Wellrounded lithoclasts are interpreted as reworked channel lag deposits from shallower parts as it has been described for instance from a land-sea transitional setting by Wehrmann et al. (2005) from the Devonian of the Rhenish Massif (Germany).

\section{FT 2: conglomeratic sandstone}

This conglomeratic sandstone facies contains approximately $5 \%$ of clasts having a ratio of sand to mud of 9:1. This facies occurs directly below facies type 1 (FT1). Because the lateral extension of the conglomerates is rather limited in the field, we interpret them to be the base of channel structures. The conglomeratic sandstone is matrix supported (Fig. 10c, sample WS-S-2). The size of the channels can reach up to $3 \mathrm{~m}$ in width. The polymict conglomerate represents sedimentary as well as volcanic rocks such as sandstones, carbonates, siltstones, and volcaniclastic rocks. The size of clasts ranges from mainly medium-sized, to occasionally coarse-sized clasts but also gravel-sized clasts occur.

Interpretation: The coarsening upward sandstones at the base, conglomeratic sandstones and conglomerates at the top with large plant fossils point to palaeoenvironmental fluctuations between fluvial and shallow-subtidal. Conglomerates were deposited in channels. Due to the size of the conglomerate clasts as well as sedimentological characteristics, the facies requires a high-energy depositional environment with certain morphology/rapid uplift of the hinterland and/or sea-level changes of appropriate magnitude. 
Fig. 7 Lithological $\log$ and conodont stratigraphy of the Hushoot Shiveetiin gol section (western part). The pyroclastic ash layer (rock sample WS-S-11) is a marker horizon which links the western and the eastern parts (= rock sample S 11) of the section. The left column shows the conodont zonation. Conodont biozones shown in black color are clearly indicated by either first appearance (FAD) or the presence of distinct taxa (including data from Suttner et al. 2020); insufficient data or no conodont data are marked with an "?" and are shown in grey color (further explanation in the text). The lithological log is subdivided into sedimentological units (Unit IV to Unit VIII). Abbreviations: for example "WS-S 42"-sedimentology/facies sample, sample numbers shown in pink were taken for geochemistry; "Wch 9"- sample for geochemistry; "HS-C-W17"- sample for conodonts)

\section{FT 3: siltstones}

Siltstones mainly represent the lowermost part of the section (Unit I, Palmatolepis minuta minuta Biozone). Low-angle silt can be seen in some laminations, often associated with smallscaled cross-bedding. The thickness of single layers varies from several millimeters to some centimeters. Some layers are unevenly laminated (particularly in the lowermost part of the section) and may represent "algal" mats which is hard to say due to silicification of the rocks. Some other layers exhibit limestone nodules which yielded rare conodonts, brachiopods, and crinoids.

\section{FT 3a: calcareous siltstones}

Calcareous siltstones mainly occur in Unit III. This facies is characterized by parallel bedding with single-layer thicknesses ranging from 0.1 to $0.5 \mathrm{~cm}$. Lamination is mainly composed of microspar laminae and peloidal laminae. Other layers do not exhibit bedding plane structures (Fig. 10d, sample HS-S-24/2). The latter feature is due to slight silicification. Some parallel beddings are enriched with pyrite and iron oxide grains, and also fecal pellets occur. Generally, the fossil content is low apart from some isolated echinoderm remains and ostracods. Some layers exhibit small-scale current ripples and/or crossbedding structures similar to the above-described facies.

Interpretation: Due to the observed sedimentological features (different ripple marks, parallel bedding), both facies settings represent a shallow-subtidal environment.

\section{FT 4: greenish, greyish, and brownish shales}

Greenish and greyish shales are the dominant rock type of Units IV to VI in the western section (Fig. 7). No sedimentary structures are visible. The small-sized grain-supported components of shales, the mixture with pyroclastic material, and the very limited number of fossils point to a palaeoenvironmental setting often with reworked sediments. Similar sedimentological characteristics are observed in the brownish shales which occur in Unit VII.
FT 4a: pyroclastic ash and volcanic ash

Pyroclastic deposits are considered as a sub-facies. These rocks occur in the entire section and are mainly intercalated in greenish-greyish shales described above. The volcaniclastic sediments are formed by accumulation of material generated by explosive fragmentation of magma and/or previously solid rock, during the course of volcanic eruptions. The components are covered by meteoric cement and exhibit normal as well as inverse gradation (Fig. 10e, sample WS-S-25/2). The latter one is an effect of gravitational differentiation of vesicular dacitic glass in the water column. Additional to the pyroclastic ash, a large number of bentonites also occur in the greenishgreyish shales (see Fig. 7) as well as in the brownish shales.

Interpretation: The pyroclastic layers (e.g. the marker horizon) and ash layers are mainly deposited within the greenishgreyish shales which represent a shallow-subtidal palaeoenvironment. The volcaniclastic sediments in the meteoric phreatic zone were subject to active water circulation and represent a shallow-water, lagoonal facies setting. The mainly dacitic composition with rare quartz components (Fig. 10f, sample WS-S-35) of the pyroclastic ash point to subductionrelated volcanism. A semi-restricted lagoon setting is supported by the evaporate minerals found in the volcanic ash layers. Evaporite minerals include gypsum, barite, and celestine. In distinct layers within greenish shales, even shallower facies conditions may have occurred where assemblages of ostracods were found representing semi-restricted lagoonal facies settings (e.g. in Unit IV, eastern section, Nazik et al. this issue). In the brownish shales of Unit VII, diversified ostracod assemblages suggest a nearshore setting which supports the palaeoenvironmental interpretation based on facies and sedimentology. All in all, facies 1 to 4 are characterized by lateral facies changes with different hydrodynamic conditions and/or minor palaeobathymetrical differences and belong to a shallow-subtidal setting.

\section{FT 5: bioclastic wackestone with stromatactis}

Fenestral fabrics as shown in Fig. 11a (sample HS-S-5) preferably occur in mudstones, packstones, and bindstones (Flügel 2004), but they are also visible in wackestones and interpretations of the genesis of those open-space structures are quite abundant (e.g. Bourque and Boulvain 1993). From our point of view, dissolution of calcareous skeletons such as the large brachiopod shells are of early diagenetic origin which is in agreement with published data by Hladil (2005), Olchowy (2011), and Vachard et al. (2017). The fabric is characterized by a large amount of detrital sediment. This facies type occurs in Unit IV (eastern part, Palmatolepis rhomboidea Biozone, samples HS-S-4, HS-S-5) in the eastern and in the equivalent part of the western section. 


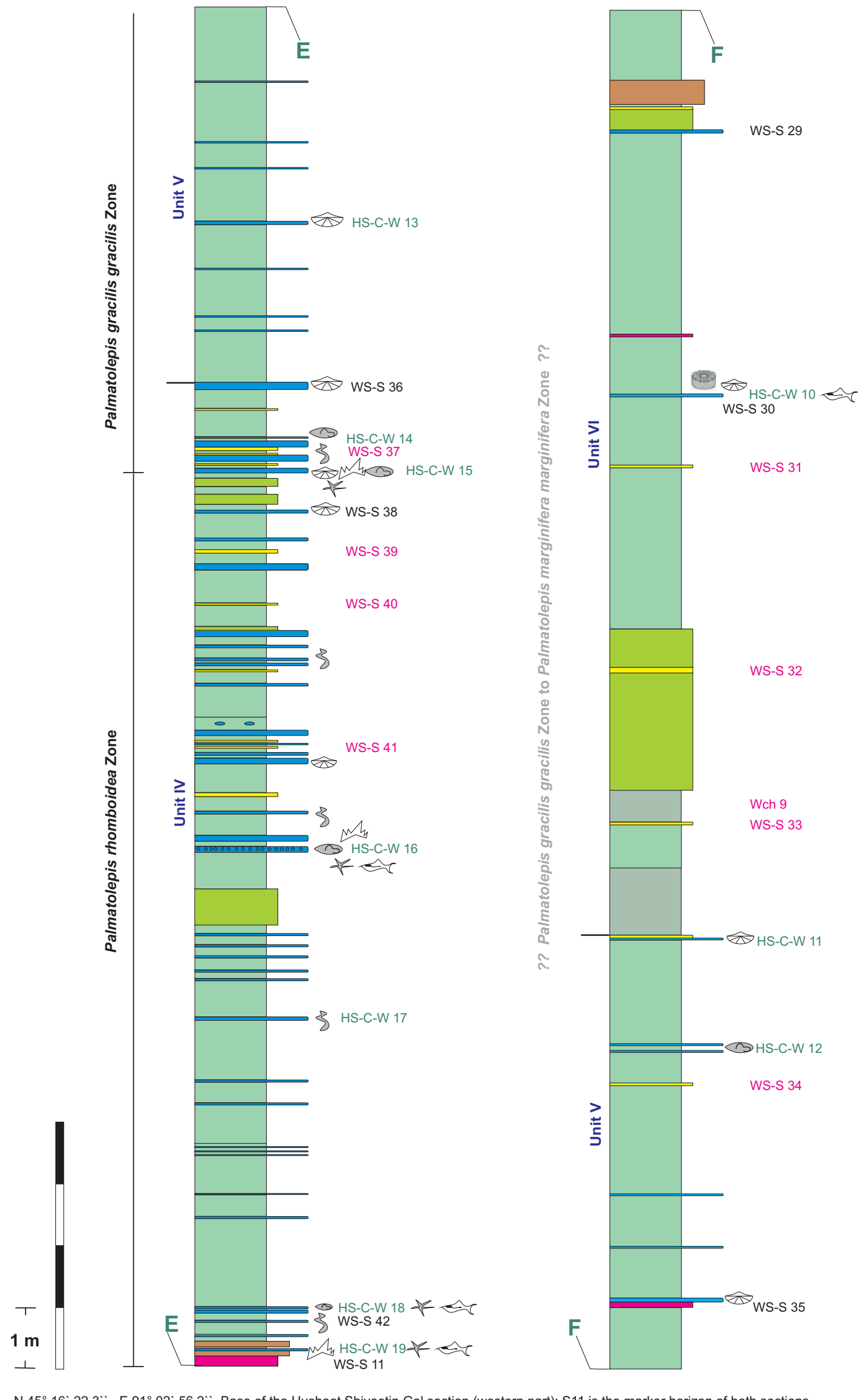

N $45^{\circ} 16^{\prime} 22.3^{\prime \prime}$ E $91^{\circ} 02^{\prime} 56.2^{\prime \prime}$ Base of the Hushoot Shiveetin Gol section (western part); S11 is the marker horizon of both sections. 


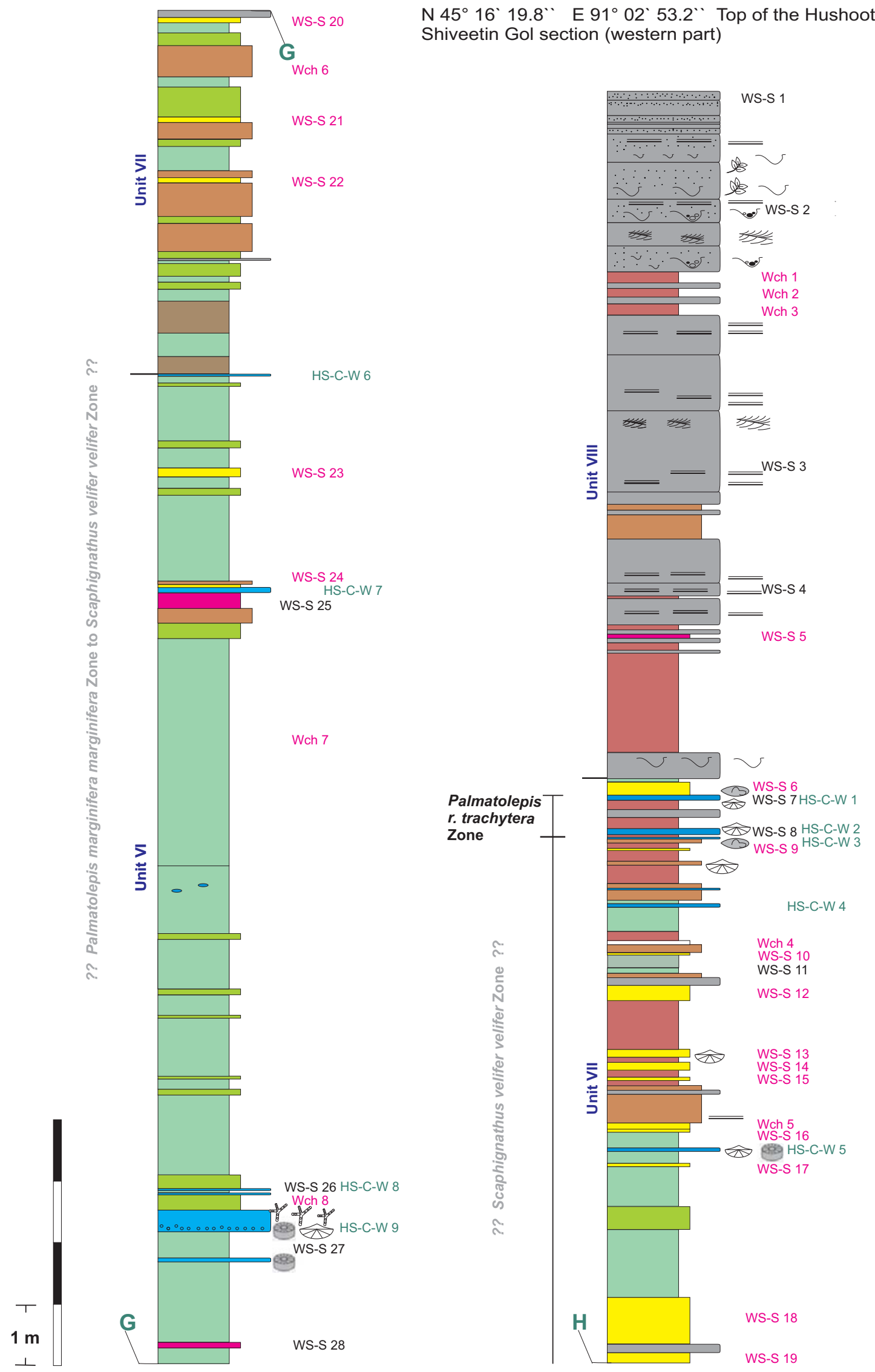

Fig. 7 (continued) 
Fig. 8 Volcaniclastic sediment discrimination diagrams for the eastern and western sections. Modelled after Wood (1980) and Bhatia and Crook (1986)

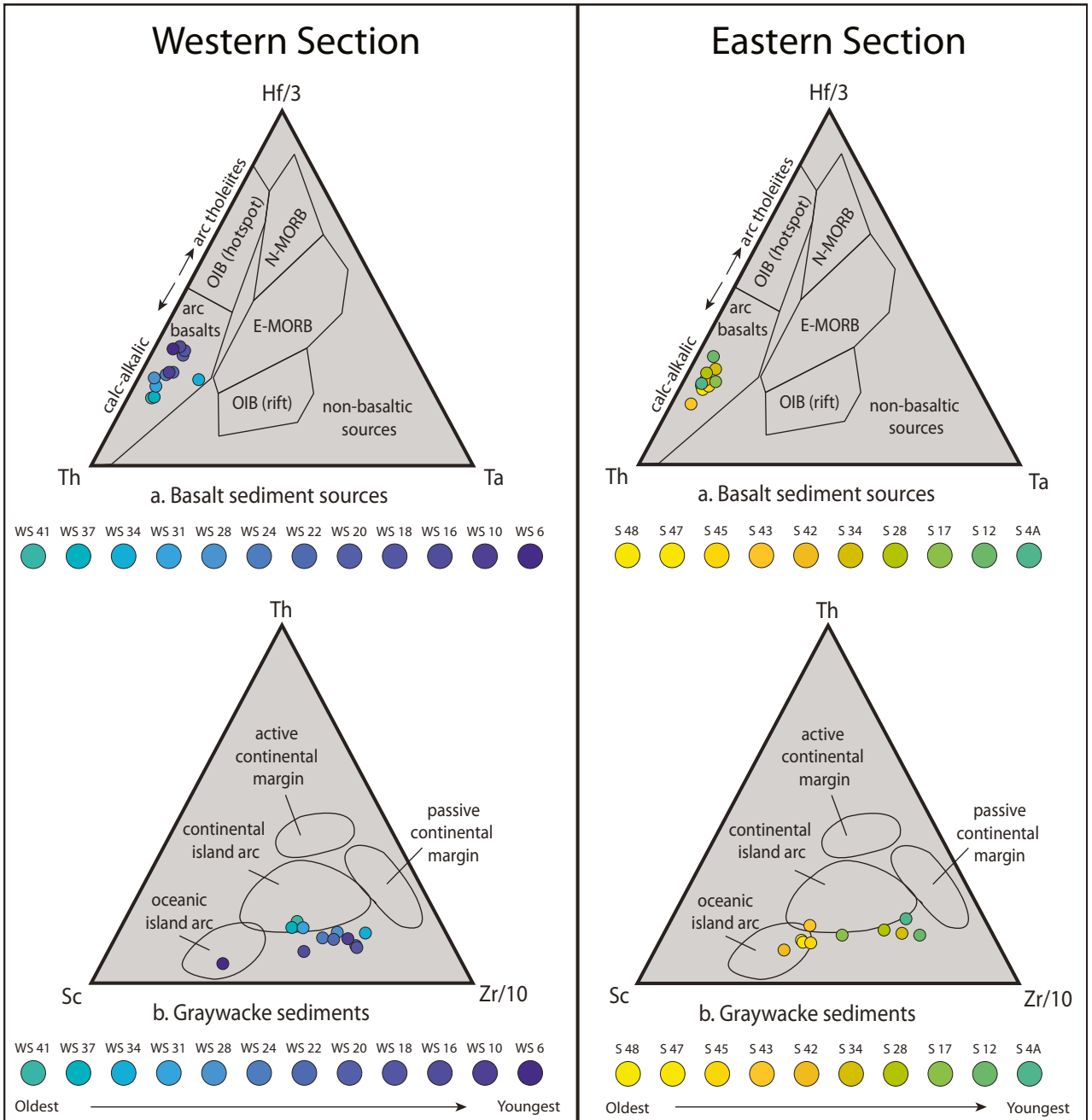

Interpretation: Fenestral fabrics (dissolved skeletal elements) represent an open-marine palaeoenvironment above fair-weather wave base (mid-ramp setting). This

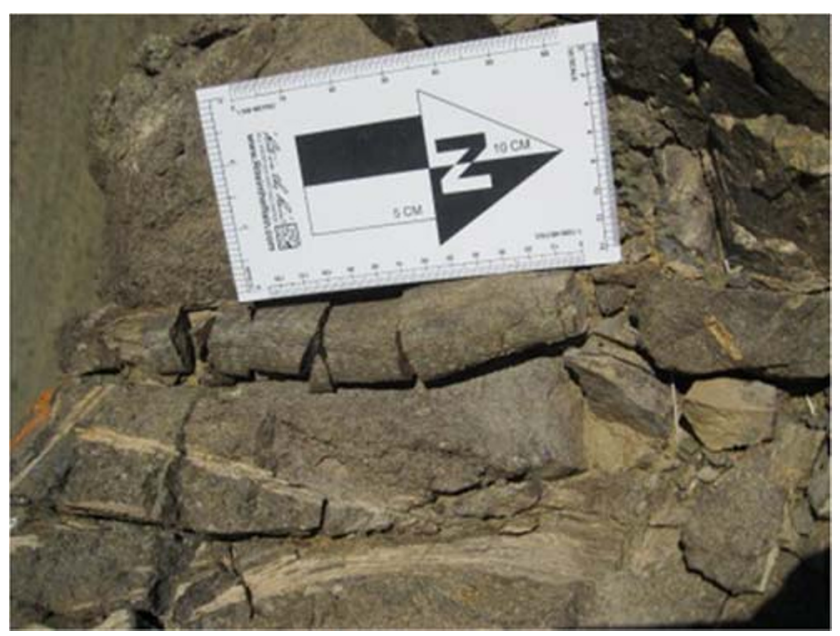

Fig. 9 Coarsening upward sandstones at the top of the Samnuuruul Formation with plant debris (large (?)lycopsid chunk) in Unit VIII of the Hushoot Shiveetiin gol section interpretation is also supported by the assemblage of ostracods, which were found in these levels (samples HS-S-4, HS-S-5). The fauna is characterized by heavyshelled and frequently broken carapaces of adult podocopids and platycopids (Nazik et al. this issue) and point to fully marine conditions.

\section{FT 6: lime mudstone/wackestone}

These micritic sediments are characterized by disintegrated skeletal material and fine erosional detritus. Bioclasts are composed of abundant sponge spicules, rare crinoid ossicles, bryozoans (cryptostome), small trilobite remnants, and ostracods (Fig. 11b, sample HS-S-10/2). Sediments are strongly burrowed. This facies occurs in distinct layers in Units III and IV.

Interpretation: Due to the size (very small) and composition of bioclasts as well as strong bioturbation, a shallow marine (mid-ramp) setting is suggested. Although sponge spicules are 
Fig. 10 Thin sections illustrating the facies of sampled rocks. a Parallel-bedded, several millimeters-thick layers (fining up) of arkosic sandstone (sample WS-S-4/2); b arkosic sandstone with lithoclasts (reworked channel lag deposit, sample (W-S-5); c matrix-supported polymict conglomeratic sandstone (sample WS-S-2); d slightly silicified calcareous siltstone with rare bioclasts (ostracods, sample HSS-24/2); e larger pyroclastic components are covered preferably isopachous fringe of cement (sample WS-S-25/2). Aragonite (light cement) and Mg-calcite cement (dark cement) have different thicknesses; f pyroclastic ash which is mainly composed of plagioclase with rare quartz components (sample WS-S-35)
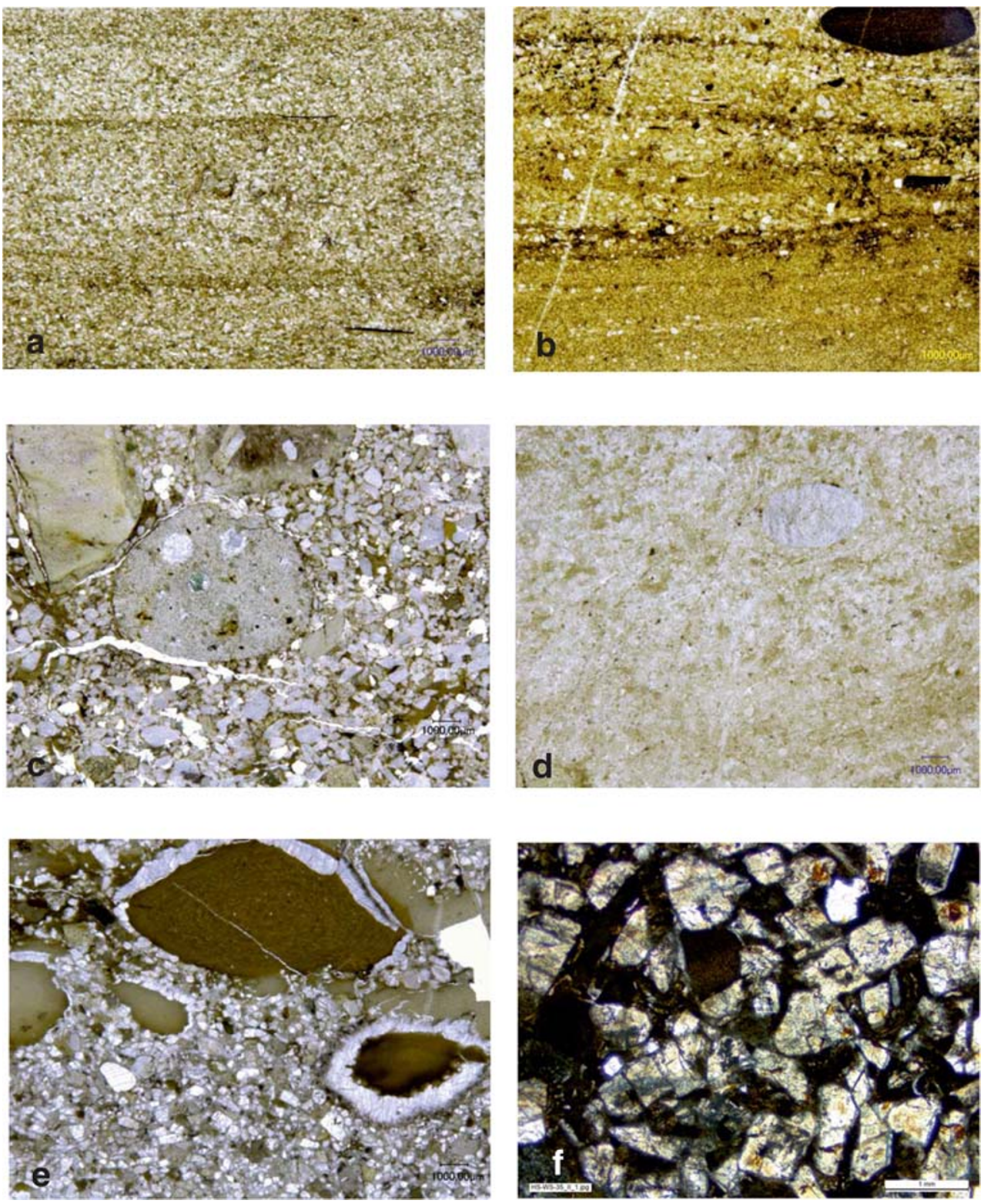

more common in deeper-water palaeoenvironments, they also occur in shallow-water settings (Gammon and James 2000).

\section{FT 7: wackestone/floatstones}

The matrix-supported carbonate rocks yield mainly echinoderms, bryozoans, brachiopods, and corals (Fig. 11c, sample WS-S-30/3); some fossils are well preserved, such as brachiopods and rare bivalves. The matrix is composed of micrite (lime mudstone). Mono-specific faunas composed of bryozoans or bryozoans and tabulate corals (Fig. 11d, sample WS-S-36/4) occur in this facies. Burrowing is common and similar to that described for FT 8.
Interpretation: These carbonates represent sediments of a low-energy palaeoenvironment below the fair-weather wave base (outer and mid ramp setting). These sediments occur as distinct layers in Unit IV (Palmatolepis glabra pectinata to Palmatolepis rhomboidea biozones) and may represent sealevel rises in combination with reduced siliciclastic/ volcaniclastic input.

\section{FT 8: bioclastic wackestone}

These carbonates exhibit a diverse fauna, such as corals, brachiopods, trilobites, and crinoid ossicles, and are partly strongly burrowed (Fig. 11e, HS-S-4/2). The matrix is mainly composed of micro-bioclastic pelmicrite, sometimes pelsparite occurs. As a result of transport, occasionally, the limestones 
Fig. 11 Thin sections illustrating the microfacies of sampled limestones. a Stromatactis in bioclastic wackestone with dissolved brachiopod shell and reworked sediments above (sample HS-S-5). b Strongly bioturbated mudstone/ wackestone with sponge spicules, trilobites, ostracods, and cryptostome bryozoans (sample HS-S-10/2). c Wackestone/ floatstone with diverse fauna (sample WS-S-30/3). d Wackestone/floatstone with tabulate corals and bryozoans covers a fine-grained bioclastic wackestone with small shell hash and sponge spicules (sample WSS-36/4). e Strongly burrowed bioclastic wackestone with crionoid ossicles; sample HS-S-4/ 2). f Laminated limestone exhibits graded bedding which points to transport by wave or storm wave activity; large number of sponge spicules refer to early diagenesis (sample HS-S-1)
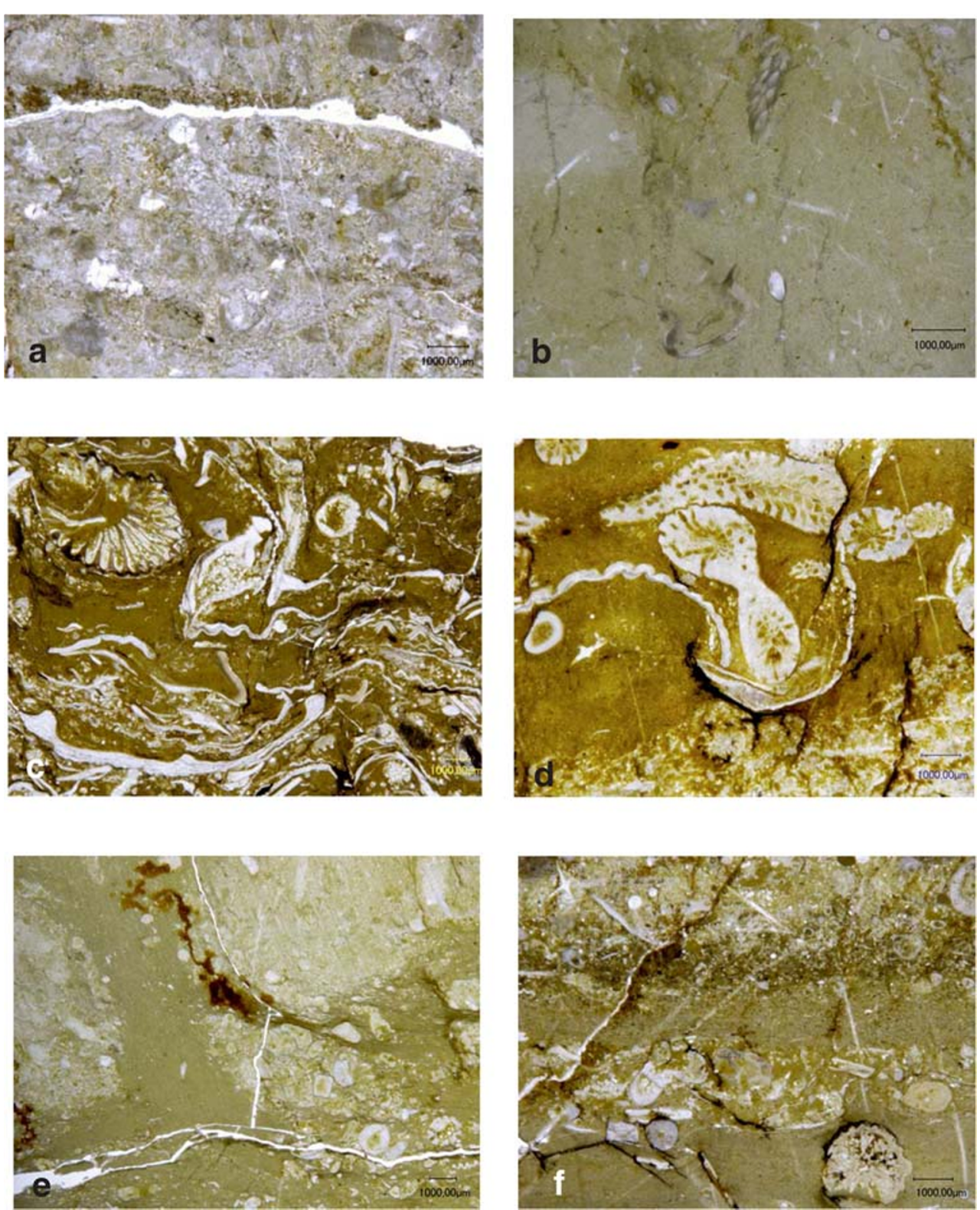

show bedding and gradation (Fig. 11f, sample HS-S-1) which reflects changes in the hydrodynamic regime. These carbonates occur in the uppermost portion of the eastern section. They can be correlated with the western part (Unit IV) where they are intercalated in greenish shales. As shown in representative samples WS-S-36/4 and HS-S-1 (Figs. 11d, f), compaction formed under burial conditions is generally weak. As a result of this solution, seams occur either in irregular thin anastomosing sutured seams in lime mudstone and/or occur in sutured seams around bioclasts.

Interpretation: These rocks are known from more openmarine palaeoenvironments as well as from shallow openshelf lagoons (Flügel 2004). The latter facies setting also occurs in our section which is supported by the ostracod assemblage in some samples (HS-C-1a, HS-C-1b, HS-C-1d) where a palaeocopid ostracod fauna was found indicating restricted or semi-restricted nearshore palaeoenvironments (Nazik et al. this issue).

\section{Discussion}

The Samnuuruul Formation of the Hushoot Shiveetiin gol section in western Mongolia was investigated in detail during two field campaigns. The section ranges biostratigraphically from the Palmatolepis minuta minuta Biozone to at least the Palmatolepis rugosa trachytera Biozone. From the biostratigraphic point of view, based on conodonts, it is obvious that hiatuses of several conodont biozones within units V, VI, and 
the basal part of Unit VII are a result of facies related predominantly to shallow-water palaeoenvironments. As a result of that, the lack of some important zonal index taxa (e.g. Palmatolepis species) hampers precise conodont biostratigraphy of those parts of the section. The application of the revised Late Devonian conodont standard biozonation (Spalletta et al. 2017) in shallow-water realms is an ecologically driven problem and well known from other studies (e.g. Bahrami et al. 2018; Königshof et al. 2020) as most species preferably occur in more deeper-water settings. Furthermore, as already discussed in Suttner et al. (2020), ecological and geomorphological barriers might be another limiting factor that significantly influenced the distribution and radiation of conodont taxa of the island arc complex of the CAOB.

The exposed Upper Devonian to Lower Carboniferous sediments represent an overall shallow-water facies setting which is mainly composed of siliciclastic rocks. The environmental setting is characterized by coeval volcanism resulting in the deposition of pyroclastic sediments. The pyroclastic ashes showing mainly dacitic composition point to subductionrelated volcanism within an intra-oceanic arc. An island arc volcanic sediment source is also confirmed by the geochemical analysis (Fig. 8).

In comparison to other sections in the Baruunhuurai Terrane (Kido et al. 2013), the Hushoot Shiveetiin gol section exhibits significant differences, such as the large amount of volcaniclastic sediments, but the sandstones and conglomerates in the uppermost part of the section are similar to other sections within the terrane. It seems likely that these sediments can be correlated with rocks of Unit IV published by Kido et al. (2013). The coarsening upward sandstones and conglomerates with interbedded siltstones and shales often containing plant fossils, such as large chunks of lycopsid stems (Kido et al. 2013, Fig. 15), are similar to the Hushoot Shiveetiin gol section. These sediments grade upwards into weathered shale and coal which most likely cross the Devonian/Carboniferous boundary (Kido et al. 2013).

According to Kaufmann's (2006) geochronology, approximately 4.7 myr separate the Palmatolepis rugosa trachytera Biozone from the D/C boundary. Becker et al. (2012) suggested a slightly shorter duration for the same interval. The sedimentary thickness from the last limestone (Palmatolepis rugosa trachytera Biozone) until the first thick-bedded sandstone in the Hushoot Shiveetiin gol section is less than $1 \mathrm{~m}$. Whether this sandstone is an equivalent to the Hangenberg sandstone (due to remarkable sea-level fall) or rather a local event due to tectonic processes remains unknown at this time. The Devonian/Carboniferous boundary is believed to occur somewhere within the Unit VIII sandstone/shale succession. Upwards, the sediments grade into thick-bedded arkosic sandstones and conglomerates with plant debris, which are assigned to the Early Carboniferous. There is no evidence for black shales and/or coal units as described in the section by Kido et al. (2013), so a possible hiatus in Unit VIII could be possible even if large-scale sedimentary discontinuities are not visible in the field. Another explanation is that the sediments described by Kido et al. (2013) represent a different depositional facies. Black shale and coal may not necessarily be preserved in high-energy marine to restricted coastal depositional environments. Thus, our section may also represent a coeval, slightly different facies setting where coal deposits did not occur.

The uppermost part of the Unit VII is represented by an increasing number of fossiliferous limestones, which are linked with transgressive pulses and more oligotrophic conditions. The latter assumption is supported by the occurrence of large numbers of platycopid ostracods. According to Lethiers and Whatley $(1994,1995)$ and Whatley et al. (2003), the "Platycopid Signal" hypothesis provides a valuable tool for studying of Oceanic Anoxic Events (OAE's) as this model indicates that the percentages of platycopid species in ostracod assemblages correlate with the ranges of dissolved oxygen levels. In a more recent paper by Horne et al. (2011), an alternative interpretation was given. Ostracod assemblages dominated by platycopids point to oligotrophic conditions. In comparison to living platycopids, they appear to be adapted to filter-feeding on nano- and picoplankton which preferably occurs in oligotrophic conditions (Horne et al. 2011). Furthermore, an increasing number of platycopids is obviously linked with transgression, whereas a decrease point to regression (Song and Gong 2019). The latter interpretation corresponds to facies analysis in this study. Transgressive pulses in the upper part of the Samnuuruul Formation are linked with the occurrence of several fossiliferous limestone layers in Unit $\mathrm{V}$ and a thick layer in Unit VI and two layers in the Palmatolepis rugosa trachytera Biozone (Fig. 7). On the other hand, the recognized transgressive pulses do not mirror the known T-R cycles in the Famennian (e.g. Johnson et al. 1985; Sandberg et al. 2002). It might be that the interglacial episode described by Sandberg et al. (2002, Event 15) previously assigned roughly to the trachytera Biozone (Sandberg et al. 1989) is represented by the last carbonate layers in our section but it seems more likely that sea-level changes are a result of regional circumstances (e.g. synsedimentary tectonics due to volcanic activity) rather than representing eustatic sea-level changes.

In a number of recent publications, volcanic eruptions have been considered as a central key to ecosystem perturbations on a variety of spatial and time scales in the Earth's history. Volcanism has been accepted as the main trigger of global biodiversity crises (Wignall 2016; Bond and Wignall 2014; In Bond and Grasby 2017; Ernst and Youbi 2017; Racki et al. 2018a, b; Clapham and Renne 2019; Racki 2019, among others). At the F/F and D/C boundaries in the Late Devonian, large-scale volcanic activity is known from some places (see papers published 
by Liu et al. 2012; Marynowski et al. 2012; Percival et al. 2018) or indirectly suggested by $\mathrm{Hg}$ anomalies (Racki et al. 2018a; Paschall et al. 2019). The environmental setting of the Hushoot Shiveetiin gol section is characterized by a very large number of coeval ash deposits, some of which have a thickness of several meters.

\section{Conclusions}

- Based on conodont stratigraphy, the Hushoot Shiveetiin gol section ranges from the Palmatolepis minuta minuta Biozone to at least the Palmatolepis rugose trachytera Biozone. Stratigraphical hiatuses of several conodont biozones occur due to depositional setting rather than folding and/or thrusting.

- The entire section most probably ranges from the Famennian to the Lower Mississippian even if we are not able to pinpoint the $\mathrm{D} / \mathrm{C}$ boundary. Based on lithological correlation with other sections in the vicinity of the Hushoot Shiveetiin gol section, it seems likely that the arkosic sandstones represent the uppermost Famennian sediments. The $\mathrm{D} / \mathrm{C}$ boundary most probably occurs somewhere in Unit VIII.

- Sedimentary structures such as ripple cross-stratification, parallel bedding, mud-pebble lags, and channel-fill structures are common throughout the section, whereas bioturbation is restricted mostly to the fossiliferous intervals, both indicating a variable depositional facies setting from shallow-intertidal to open marine. Palaeoenvironmental interpretations provided by facies analysis are also in agreement with evaporite minerals found in the volcanic ash layers.

- Macrofossils were found in this section in distinct horizons, such as trilobites, bryozoans, echinoderms, and brachiopods. Whereas some groups are relatively abundant and diverse such as trilobites and bryozoans, and in particular echinoderms and ostracods, brachiopods show a low to moderate diversity which is most probably related to somewhat restricted conditions and/or triggered by the intensive volcanic activity during the Famennian in this area.

- The diverse ostracod Eifelian Mega-Assemblage I-III (Nazik et al. this issue) expanding from shallow-water refugia supports the idea of the $\mathrm{CAOB}$ as a biodiversity hotspot in the aftermath of the F/F extinction as it was already shown from other fossil groups (Waters et al. 2003; Webster and Waters 2009; Ernst 2013).

Acknowledgements We are grateful to Jana Anger (Senckenberg Institute, Frankfurt) for conodont and thin section preparation. Hanna Cieszynski (Cologne) took the REM photographs of conodont sample HS-C-W1. We also thank the entire Mongolian team for their tremendous support in preparing the expedition and during our stay in the field camp. We thank Gary Webster (USA) and an anonymous reviewer for their comments and suggestions. This paper is a contribution to IGCP Project 652 ("Reading geologic time in Paleozoic sedimentary rocks: the need for an integrated stratigraphy [2017-2021]").

Funding Open Access funding enabled and organized by Projekt DEAL. M. Ariuntogos received funding from the German Academic Exchange Service (DAAD, Research Grant - Doctoral Program in Germany, September 01, 2018-September 01, 2021; 57381412). P. Königshof has received funding from Deutsche Forschungsgemeinschaft (DFG KO-1622/19-1). Sarah Carmichael and Johnny Waters received support from National Geographic (CP-113R-17) and Appalachian State University. Allison Dombrowski and Olivia Paschall receiving funding from the Explorers Club Youth Activity Fund and Appalachian State University.

\section{Compliance with ethical standards}

Conflict of interest The authors declare that they have no conflict of interest.

Open Access This article is licensed under a Creative Commons Attribution 4.0 International License, which permits use, sharing, adaptation, distribution and reproduction in any medium or format, as long as you give appropriate credit to the original author(s) and the source, provide a link to the Creative Commons licence, and indicate if changes were made. The images or other third party material in this article are included in the article's Creative Commons licence, unless indicated otherwise in a credit line to the material. If material is not included in the article's Creative Commons licence and your intended use is not permitted by statutory regulation or exceeds the permitted use, you will need to obtain permission directly from the copyright holder. To view a copy of this licence, visit http://creativecommons.org/licenses/by/4.0/.

\section{References}

Algeo, T. J., \& Scheckler, S. E. (1998). Terrestrial-marine teleconnections in the Devonian: links between the evolution of land plants, weathering processes, and marine anoxic events. Philosophical Transactions of The Royal Society, B Biological Sciences, 353(1365), 113-130. https://doi.org/10.1098/rstb.1998. 0195 .

Ariunchimeg, Ya. (2000). The first finds of Famennian Bryozoans in Mongolia. Paleontologicheskii Zhurnal 1, 45-48. (in Russian).

Ariunchimeg, Ya., Bayasgalan, A., Waters, J. A., Kido, E., Suttner, T. J., Sersmaa, G., Undariya, J., \& Otgonbaatar, D. (2014). IGCP 596 IGCP580 Field Workshop Guidebook. 8-18th August, 2014, Ulaanbaatar, Mongolia. Paleontological Center, Mongolian Academy of Sciences, 1-55.

Ashouri, A.R. (2006). Middle Devonian-Early Carboniferous conodont faunas from the Khoshyeilagh Formation, Alborz Mountains, north Iran. Journal of Sciences, 17, 53-65.

Badarch, G., Byamba, J., Mahbadar, Ts., Minjin, Ch., Orolmaa, D., Tumurtogoo, O., \& Khosbayar, Ts. (1998). Summary. In: Tumurtogoo, O., Byamba, J., Badarch, G., Minjin, Ch., Orolmaa, D., Khosbayar, Ts., Chuluun, D., Makhbadar, Ts. \& Bat-Ireedui, Ya. (1998). Geological map of Mongolia, scale 1:1,000,000: Mineral resources Authority of Mongolia. Geological Survey and Mongolian Academy of Sciences, Institute of Geology and Mineral Resources, Ulaanbaatar, 1-30. (in Mongolian). 
Bahrami, A., Königshof, P., Boncheva, I., Yazdi, M., Ahmadi Nahre Khalaji, M., \& Zarei, E. (2018). Conodont biostratigraphy of the Kesheh and Dizlu sections, and the age range of the Bahram formation in Central Iran. Palaeobiodiversity and Palaeoenvironments, 98, 315-329. https://doi.org/10.1007/s12549-017-0307-y.

Bahrami, A., Königshof, P., Vaziri-Moghaddam, H., Shakeri, B., \& Boncheva, I. (2019). Conodont stratigraphy and conodont biofacies of the shallow-water Kuh-e-Bande-Abdol-Hossein section (SE Anarak, Central Iran). Palaeobiodiversity and Palaeoenvironments, 99, 477-494. https://doi.org/10.1007/s12549019-00384-5.

Barskov, I. S., Vorontzova, T. N., Kononova, L. I., \& Kuzmin, A. V. (1991). Index conodonts of the Devonian and Lower Carboniferous. Moskowskiy gosudarstvenniy universitet, 183.

Becker, R. T., Gradstein, F. M., \& Hammer, O. (2012). The Devonian period. In F. M. Gradstein (Ed.), The Geologic Time Scale (Vol. 2, pp. 559-601). https://doi.org/10.1016/B978-0-444-59425-9.000226.

Becker, R. T., Königshof, P., \& Brett, C. E. (Eds). (2016). Devonian climate, sea level and evolutionary events: an introduction. Geological Society of London, Special Publication 432, 1-10. https://doi.org/10.1144/SP423.15.

Bhatia, M. R., \& Crook, K. A. W. (1986). Trace element characteristics of graywackes and tectonic setting discrimination of sedimentary basins. Contributions to Mineralogy and Petrology, 92(2), 181-193. https://doi.org/10.1007/BF00375292.

Blumenstengel, H. (1969). Oberdevonische Ostracoden aus der Bohrung Mandelholz 18/56 (Harz, Elbingeroder Komplex). Freiberger Forschungshefte C, 256, 7-36.

Bolshakova, L. N., Bondarenko, O. B., Minjin, Ch., Ulitina, L. M., \& Sharkova, T. T. (2003). Paleontology of Mongolia: corals and stromatoporoids. Nauka, Moskow, pp. 199-256, (in Russian).

Bond, D. P. G., \& Grasby, S. E. (2017). On the causes of mass extinctions. Palaeogeography Palaeoclimatology Palaeoecology, 478, 3 29. https://doi.org/10.1016/j.palaeo.2016.11.005

Bond, D. P. G., \& Wignall, P. B. (2014). Large igneous provinces and mass extinctions: an update. In G. Keller and A.C. Kerr, (Eds.), Volcanism, Impacts, and mass extinctions: causes and effects, Geological Society of America, Special Paper 505, 339-352, https://doi.org/10.1130/2014.2505(02).

Bourque, P. A., \& Boulvain, F. (1993). A model for the origin and petrogenesis of the red stromatactis limestone of Paleozoic carbonate mounds. Journal of Sedimentary Petrology, 63(4), 607-619. https:// doi.org/10.1306/D4267B8B-2B26-11D7-8648000102C1865D.

Brice, D., Carls, P., Cocks, L. R. M., Copper, P., Garcia-Alcalde, J. L., Godefroid, J., \& Racheboeuf, P. R. (2000). Brachiopoda. In P. Bultynck, (Ed.), Subcommission on Devonian stratigraphy - fossil groups important for boundary definition. Courier Forschungsinstitut Senckenberg 220, 65-86.

Carmichael, S. K., Water, J. A., Königshof, P., Suttner, T. J., \& Kido, E. (2019). Paleogeography and paleoenvironments of the Late Devonian Kellwasser event: a review of its sedimentological and geochemical expression. Global and Planetary Change 183, 1-25. https://doi.org/10.1016/j.gloplacha.2019.102984.

Carmichael, S. K., Waters, J. A., Suttner, T. J., Kido, E., \& DeReuil, A. A. (2014). A new model for the Kellwasser anoxia events (Late Devonian): shallow water anoxia in an open oceanic setting in the Central Asian Orogenic Belt. Palaeogeography, Palaeoclimatology, Palaeoecology, 399, 394-403. https://doi.org/10.1016/j.palaeo. 2014.02.016.

Chlupáć, I. (1975). The distribution of phacopid trilobites in space and time. Fossils and Strata, 4, 399-408.

Choulet, F., Cluzel, D., Faure, M., Lin, W., Wang, B., Chen, Y., Wu, F. Y., \& Ji, W. (2012). New constraints on the pre-Permian continental crust growth of Central Asia (West Junggar, China) by U-Pb and Hf isotopic data from detrital zircon. Terra Nova, 24, 189-198. https:// doi.org/10.1111/j.1365-3121.2011.01052.x.

Clapham, M. E., \& Renne, P. R. (2019). Flood basalts and mass extinctions. Annual Review of Earth and Planetary Sciences, 47, 275-303.

Copper, P. (1998). Evaluating the Frasnian-Famennian mass extinction: comparing brachiopod faunas. Acta Palaeontologica Polonica, 43, $137-154$.

Crasquin, S., \& Horne, D. J. (2018). The Palaeopsychrosphere in the Devonian. Lethaia, 51, 547-563. https://doi.org/10.1111/let.12277.

Crônier, C., \& François, A. (2014). Distribution patterns of Upper Devonian phacopid trilobites: paleobiogeographical and paleoenvironmental significance. Palaeogeography, Palaeoclimatology, Palaeoecology, 404, 12-23.

Crônier, C., Malti, F. Z., François, A., Benyoucef, M., \& Brice, D. (2013). First occurrence of a phacopid trilobite faunule from the Upper Devonian of Saoura Valley, Algeria and biodiversity fluctuations. Geological Magazine, 150, 1002-1021.

Crônier, C., Ariuntogos, M., Königshof, P., Waters, J., \& Carmichael, S. (this issue). Late Devonian (Famennian) phacopid trilobites from western Mongolia. https://doi.org/10.1007/s12549-020-00449-w.

Curry, G. B., \& Brunton, C. H. C. (2007). Stratigraphic distribution of brachiopods. In P.A. Selden, (Ed.), Treatise on invertebrate Paleontology, Part H Brachiopod, 6, supplement: 2901-2965. Boulder, Colorado and Lawrence, Kansas, Geological Society of America Inc. and University of Kansas.

De Vleeschouwer, D., Rakociński, M., Racki, G., Bond, D. P. G., Sobień, K., \& Claeys, P. (2013). The astronomical rhythm of late-Devonian climate change (Kowala section, Holy Cross Mountains, Poland). Earth and Planetary Science Letters, 365, 25-37. https://doi.org/10. 1016/j.epsl.2013.01.016.

Dergunov, A. B. (Ed.) (2001). Tectonics, Magmatism, and Metallogeny of Mongolia. London-New York, Routledge, 288.

Donskaya, T. V., Gladkochub, D. P., \& Mazukabzov, A. M. (2013). Late Paleozoic-Mesozoic subduction-related magmatism at the southern margin of the Siberian continent and the 150 million-year history of the Mongol-Okhotsk Ocean. Journal of Asian Earth Sciences, 62, 79-97. https://doi.org/10.1016/j.jseaes.2012.07.023.

Epstein, A. G., Epstein, J. B., \& Harris, L. D. (1977). Conodont colour alteration - an index to organic metamorphism. Geological Survey of America, Professional Paper, 995, 1-27.

Ernst, A. (2013). Diversity dynamics and evolutionary patterns of Devonian Bryozoa. Paleobiodiversity and Paleoenvironments, 93(1), 45-63. https://doi.org/10.1007/s12549-012-0086-4.

Ernst, R. E., \& Youbi, N. (2017). How large igneous provinces affect global climate, sometimes cause mass extinctions, and represent natural markers in the geological record. Palaeogeography, Palaeoclimatology, Palaeoecology, 478, 30-52. https://doi.org/10. 1016/j.palaeo.2017.03.014.

Feist, R. (2019). Post-Kellwasser event recovery and diversification of phacopid trilobites in the early Famennian (Late Devonian). Bulletin of Geosciences, 94, 1-22.

Flügel, E. (2004). Microfacies of carbonate rocks. Berlin: Springer.

Folk, R. L. (1954). The distinction between grain size and mineral composition in sedimentary-rock nomenclature. The Journal of Geology, 62(4), 344-359. https://doi.org/10.1086/626171.

Gammon, P. R., \& James, N. P. (2000). Palaeogeographical influence on Late Eocene biosiliceous sponge-rich sedimentation, Southern Western Australia. Sedimentology, 48(3), 559-584. https://doi.org/ 10.1046/j.1365-3091.2001.00379.x.

Gimenez-Montsant, J., Calvet, F., \& Tucker, M. E. (1999). Silica diagenesis in Eocene shallow-water platform carbonates, southern Pyrenees. The Journal of the International Association of Sedimentologists, Sedimentology, 46(6), 969-984. https://doi.org/ 10.1046/j.1365-3091.1999.00231.x.

Hartenfels, S. (2011). Die globalen Annulata-Events und die DasbergKrise (Famennium, Oberdevon) in Europa und Nord-Afrika - 
hochauflösende Conodonten-Stratigraphie, Karbonat-Mikrofazies, Paläoökologie und Paläodiversität. Münsterische Forschungen zur Geologie und Paläontologie, 105, 17-527.

Hartenfels, S., \& Becker, R. T. (2016). Famennian sedimentation, faunas, and event stratigraphy at Effenberg Quarry (Remscheid-Altena Anticline, Rhenish Massif). Münstersche Forschungen zur Geologie und Paläontologie, 108, 141-157.

Hladil, J. (2005). The formation of stromatactis-type fenestral structures during the sedimentation of experimental slurries-a possible clue to a 120-year-old puzzle about stromatactis. Bulletin of Geosciences, 80(3), 193-211.

Horne, D. J., Brandāo, S. N., \& Slipper, I. J. (2011). The Platycopid signal deciphered: responses of ostracod taxa to environmental change during the Cenomanian-Turonian boundary event (Late Cretaceous) in SE England. Elsevier, Palaeogeography, Palaeoclimatology, Palaeoecology, 308(3-4), 304-312. https:// doi.org/10.1016/j.palaeo.2011.05.034.

Johnson, J. G., Klapper, G., \& Sandberg, C. A. (1985). Devonian eustatic fluctuations in Euramerica. Geological Society of America Bulletin, 96, 567-587.

Kaiser, S. I., Aretz, M., \& Becker, R. T. (2016). The global Hangenberg Crisis (Devonian-Carboniferous transition): review of a first-order mass extinction. In R. T. Becker, P. Königshof, \& C. E. Brett (Eds.), Devonian climate, sea level and evolutionary events. Geological Society, London, Special Publications 423, 387-437.

Kaufmann, B. (2006). Calibrating the Devonian time scale: a synthesis of $\mathrm{U}-\mathrm{Pb}$ ID-TIMS ages and conodont stratigraphy. Earth-Science Reviews, 76, 175-190. https://doi.org/10.1016/j.earscirev.2006.01. 001.

Kido, E., Suttner, T. J., Waters, J. A., Ariunchimeg, Y., Sersmaa, G., Atwood, J. W., \& Webster, G. D. (2013). Devonian deposits of the Baruunkhuurai Terrane, western Mongolia (IGCP 596 Field Workshop). Episodes, 36(4), 242-254. https://doi.org/10.18814/ epiiugs/2013/v36i4/001.

Königshof, P., Bahrami, A., \& Kaiser, S. I. (2020). DevonianCarboniferous boundary sections in Iran. In M. Aretz \& C. Corradini (Eds.), Devonian-Carboniferous boundary. Palaeobiodiversity and Palaeoenvironments (in press). https://doi.org/10.1007/s12549-020000438-z.

Lane, N. G., Waters, J. A., \& Maples, C. G. (1997). Echinoderm faunas of the Hongguleleng Formation, Late Devonian (Famennian), XinjianUygur Autonomous Region, China. Paleontological Society. Memoir, 47, 1-43.

Lazarev, S. S., \& Suurisuren, Sh. (1992). New productids (Brachiopoda) from Carboniferous of Mongolia. In: Grunt, T.A (Ed.), New Taxa of invertebrate fossils from Mongolia, Trudy joint Russian/Mongolian paleontological expedition vol. 41, 61-70 (in Russian).

Lerosey-Aubril, R., \& Feist, R. (2012). Quantitative approach of diversity and decline in late Palaeozoic trilobites. In J. A. Talent (Ed.), Earth and life: global biodiversity, extinction intervals and biogeographic perturbations through time (pp. 535-555). Springer Publishing.

Lethiers, F., \& Casier, J.G. (1996). Les Ostracodes survivants à l'événement F/F dans le limitotype de Coumiac (Montagne Noire, France). Annales de la Société géologique de Belgique, 117(1), 137153

Lethiers, F., \& Whatley, R. (1994). The use of Ostracoda to reconstruct the oxygen levels of Late Paleozoic oceans. Marine Micropaleontology, 24, 57-69. https://doi.org/10.1016/03778398(94)90011-6.

Lethiers, F., \& Whatley, R. (1995). Oxygénation des eaux etostracodes filtreurs: Application au Devonien-Dinantien. Geobios, 28(2), 199207. https://doi.org/10.1016/S0016-6995(95)80227-4.

Li, P., Sun, M., Rosenbaum, G., Jourdan, F., Li, S., \& Cai, K. (2017). Late Paleozoic closure of the Ob-Zaisan Ocean along the Irtysh Shear zone (NW China): implications for arc amalgamation and oroclinal bending in the Central Asian Orogenic Belt. Geological
Society of America Bulletin, 129(5-6), 547-569. https://doi.org/10. 1130/B31541.31541.

Liu, Y.-Q., Ji, Q., Kuang, H.-W., Jiang, X.-J., Xu, H., \& Peng, N. (2012). $\mathrm{U}-\mathrm{Pb}$ zircon age, sedimentary facies, and sequence stratigraphy of the Devonian-Carboniferous boundary, Daposhang Section, Guizhou, China. Palaeoworld, 21(2), 100-107. https://doi.org/10. 1016/j.palwor.2012.03.001.

Marynowski, L., Zatoń, M., Racońcinski, M., Filipiak, P., Kurkiewicz, S., \& Pearce, T. J. (2012). Deciphering the upper Famennian Hangenberg Black Shale depositional environments based on multi-proxy record. Palaeogeography, Palaeoclimatology, Palaeoecology, 346, 66-86.

Metcalfe, I. (2011). Palaeozoic-Mesozoic history of SE Asia. Geological Society, London, Special Publications, 355, 7-35. https://doi.org/10. 1144/SP355.2.

Nazik, A., Königshof, P., Ariuntogos, A., Waters, J. A., \& Carmichael, S. K. (this issue). Late Devonian ostracods from the Hushoot Shiveetiin gol island arc section (Baruunhuurai Terrane, western Mongolia) and their palaeoenvironmental implication and palaeobiogeographic relationship. https://doi.org/10.1007/s12549020-00446-z.

Olchowy, P. (2011). Possible origin of stromatactis-like cavities in Upper Jurassic sediments from the Wielkanoc quarry near Gocza (KrakowCzestochowa Upland, southern Poland)-experimental studies. Facies, 57(4), 613-625. https://doi.org/10.1007/s10347-010-02629.

Paschall, O. C., Carmichael, S. K., Königshof, P., Waters, J. A., Ta, P. H., Komatsu, T., \& Dombrowski, A. (2019). The Hangenberg Event in Vietnam: sustained ocean anoxia with a volcanic trigger? Global and Planetary Change, 175, 64-81. https://doi.org/10.1016/j. gloplacha.2019.01.021.

Percival, L., Davies, J., Schaltegger, U., De Vleeschouwer, D., Da Silva, A.-C., \& Föllmi, K. (2018). Precisely dating the FrasnianFamennian boundary: implications for the cause of the Late Devonian mass extinction. Scientific Reports, 8(1), 9578.

Pettijohn, F. J., Potter, P. E., \& Siever, R. (1973). Sand and sandstone (Vol. 617). Berlin: Springer-Verlag.

Racki, G. (2005). Toward understanding Late Devonian global events: few answers, many questions. In D. J. Over, J. R. Morrow, \& P. B. Wignall (Eds.), Understanding Late Devonian and PermianTriassic Biotic and Climatic Events: Towards an Integrated Approach (Vol. 20, pp. 5-36). https://doi.org/10.1016/S09205446(05)80002-0.

Racki, G. (2019). Volcanism as a prime cause of mass extinctions: retrospectives and perspectives. In T. Adatte, D. P. G. Bond, \& G. Keller (Eds.), Mass extinctions, volcanism, and impacts: new developments (p. 544). Geological Society of America Special Paper. https://doi. org/10.1130/2019.2544(01.

Racki, G., Rakociński, M., \& Marynowski, L. (2018a). Anomalous Upper Devonian mercury enrichments: comparison of inductively coupled plasma-mass spectrometry (ICPMS) and AAS analytical data. Geology Quarterly, 62(3), 487-495. https://doi.org/10.7306/ gq.1419.

Racki, G., Rakociński, M., \& Wignall, P. B. (2018b). Mercury enrichments and the Frasnian-Famennian biotic crisis: a volcanic trigger proved? Geology, 46, 543-546. https://doi.org/10.1130/G40233.1.

Ruzhentsev, S. V., Pospeleov, I. I., \& Badarch, G. (1992). Tectonics of Baruunkhuurai Basin, Mongolia. Geotectonics, 22(1), 67-77.

Safonova, I., Kotlyarov, A., Krivonogov, S., \& Xiao, W. (2017). Intraoceanic arcs of the Paleo-Asian Ocean. Gondwana Research, 50, 167-194. https://doi.org/10.1016/j.gr.2017.04.005.

Sandberg, C. A., Morrow, J. R., \& Ziegler, W. (2002). Late Devonian sealevel changes, catastrophic events, and mass extinctions. In C. Koeberl, \& K.G. MacLeod, (Eds.), Catastrophic events and mass extinctions: impacts and beyond. Boulder, Colorado, Geological Society of America special paper 356, 473-487. 
Sandberg, C.A., Ziegler, W., \& Bultynck, P. (1989). New standard conodont zones and early Ancyrodella phylogeny across the MiddleUpper Devonian boundary. Courier Forschungsinstitut Senckenberg, 110, 195-230. https://doi.org/10.3140/bull.geosci. 1623.

Sepkoski, J. J. (1996). Patterns of Phanerozoic extinction: a perspective from global data bases. In O. H. Walliser (Ed.), Global events and event stratigraphy in the Phanerozoic (pp. 35-51). Berlin: SpringerVerlag. https://doi.org/10.1007/978-3-642-79634-0_4.

Song, J. J., \& Gong, Y. M. (2019). Ostracods from the DevonianCarboniferous transition in Dushan of Guizhou, South China. In W.K. Qie, K. Liang, \& P. Königshof, (Eds). Devonian palaeoecosystems and palaeoenvironment of South China. Palaeobiodiversity and Palaeoenvironments 99(1), 117-127. https://doi.org/10.1007/s12549-018-0322-7.

Song, H. J., Algeo, T. J., Tong, J. N., Romaniello, S. J., Zhu, Y. Y., Chu, D. L., \& Anbar, A. D. (2017). Uranium and carbon isotopes document global-ocean redox-productivity relationships linked to cooling during the Frasnian-Fammenian mass extinction. Geology, 45, 887-890. https://doi.org/10.1130/G39393.1.

Song, J. J., Crasquin, S., \& Gong, Y. M. (2019). Late Devonian benthic ostracods from western Junggar, NW China: implications for palaeoenvironmental reconstruction. Geological Journal, 54(1), $91-100$

Spalletta, C., Perri, M. C., Over, D. J., \& Corradini, C. (2017). Famennian (Upper Devonian) conodont zonation: revised global standard. Bulletin of Geosciences, 91, 31-57. https://doi.org/10.3140/bull. geosci.1623.

Stachacz, M., Kondas, M., Filipiak, P., \& Ma, X. (2020). Environment and age of the Upper Devonian-Carboniferous Zhulumute and Hongguleleng Formations (Junggar Basin, NW China): Ichnological and Palynological Aspects. Acta Geologica SinicaEnglish Edition, 1-23. https://doi.org/10.1111/1755-6724.14408.

Stein, W. E., Mannolini, F., Hernick, L. V., Landing, E., \& Berry, C. M. (2007). Giant cladoxylopsid trees resolve the enigma of the Earth's earliest forest stumps at Gilboa. Nature, 446, 904-907. https://doi. org/10.1038/nature05705.

Suttner, T. J., Kido, E., Chen, X. Q., Mawson, R., Waters, J. A., Frýda, J., Mathieson, D., Molloy, P. D., Pickett, J., Webster, G. D., \& Frýdová, B. (2014). Stratigraphy and facies development of the marine Late Devonian near the Boulongour Reservoir, northwest Xinjiang, China. Journal of Asian Earth Sciences, 80, 101-118. https://doi.org/10.1016/j.jseaes.2013.11.001.

Suttner, T.J., Kido, E., Ariunchimeg, Ya., Sersmaa, G., Waters, J.A., Carmichael, S.K., Batchelor, C.J., Ariuntogos, M., Hušková, A., Slavík, L., Valenzuela-Ríos, J.I., Liao, J.-C., \& Gatovsky, Y. A. (2020). Conodonts from Late Devonian island arc settings (Baruunkhuurai Terrane, western Mongolia). Palaeogeography, Palaeoclimatology, Palaeoecology, 549, 1-22. https://doi.org/10. 1016/j.palaeo.2019.03.001.

Talent, J. A., \& Mawson, R. (1999). North-eastern Molong Platform and adjacent Hill End Trough, New South Wales: mid Palaeozoic conodont data, age-inferences, and implifications regarding platform exposure and carbonate sedimentation offshore. Abhandlungen der Geologischen Bundesanstalt (Wien), 54, 49-105.

Tucker, M. E. (2001). Sedimentary petrology: an introduction to the origin of sedimentary rocks. Oxford, 3rd edition, 262.

Tucker, M. E., \& Wright, V. P. (1990). Carbonate sedimentology (Vol. 482). Oxford: Blackwell. https://doi.org/10.1002/9781444314175.

Tumurtogoo, O. (2014). Tectonics of Mongolia. In Yu.G. Leonov, O.V. Petrov, \& I.I. Pospelov, (Eds.), Tectonics of northern, central and eastern Asia. Explanatory note to the tectonic map of northerncentral-eastern Asia and adjacent areas at scale 1:2,500,000. SPb.: VSEGEI Printing House, 184.

Vachard, D., Dreesen, R., Marion, J.-M., \& Mottequin, B. (2017). New data on the incertae sedis biota and foraminifera of the mid-
Famennian Baelen Member (Late Devonian, eastern Belgium). In B. Mottequin, L. Slavik, \& P. Königshof, (Eds.), Climate change and biodiversity patterns in the mid-Palaeozoic. Palaeobiodiversity and Palaeoenvironments 97(3), 565-585.

Walliser, O. H. (1996). Global events in the Devonian and Carboniferous. In O. H. Walliser (Ed.), Global events and event stratigraphy in the Phanerozoic (pp. 225-250). Berlin, Heidelberg: Springer.

Wang, Z., Becker, R., Aboussalam, Z., Hartenfels, S., Joachimski, M., \& Gong, Y. (2016). Conodont and carbon isotope stratigraphy near the Frasnian/Famennian (Devonian) boundary at Wulankeshun, Junggar Basin, NW China. Palaeogeography, Palaeoclimatology, Palaeoecology, 448, 279-297.

Waters, J. A., Maples, C. G., Lane, N. G., Marcus, S., Liao, Z., Liu, L., Hou, H., \& Wang, J. (2003). A quadrupling of Famennian pelmatozoan diversity: New Late Devonian blastoids and crinoids from northwest China. Journal of Paleontology, 77(5), 922-948. https://doi.org/10.1017/S0022336000044772.

Waters, J. A., Waters, J., Königshof, P., Carmichael, S., Ariuntogos, M. Famennian Crinoids and Blastoids (Echinodermata) from Mongolia (this issue). https://doi.org/10.1007/s12549-020-00450-3.

Webster, G. D., \& Waters, J. A. (2009). Late Devonian echinoderms from the Hongguleleng Formation of northwestern China. In P. Königshof (Ed.), Devonian change: case studies in Palaeogeography and Palaeoecology, Geological Society of London, special publication (Vol. 314, pp. 263-287). https://doi. org/10.1144/SP314.14.

Wehrmann, A., Hertweck, G., Brocke, R., Jansen, U., Königshof, P., Plodowski, G., Schindler, E., Wilde, V., Blieck, A., \& Schultka, S. (2005). Paleoenvironment of an Early Devonian Land-Sea transition: a case study from the southern margin of the Old Red Continent (Mosel Valley, Germany). Palaios, 20(2), 101-120. https://doi.org/10.2110/palo.2003.p03-33.

Whatley, R., Pyne, R. S., \& Wilkinson, I. P. (2003). Ostracoda and palaeo-oxygen levels, with particular reference to the Upper Cretaceous of East Anglia. Palaeogeography Palaeoclimatology Palaeoecology, 194(4), 355-386. https://doi.org/10.1016/S00310182(03)00333-X

Wignall, P. B. (2016). The worst of times how life on Earth survived eighty million years of extinctions: Princeton, Princeton University Press, 224.

Wilson, I. G. (1975). Carbonate facies in geologic history (Vol. 471) Berlin: Springer-Verlag.

Windley, B. F., Alexeiev, D., Xiao, W., Kröner, A., \& Badarch, G. (2007). Tectonic models for accretion of the Central Asian Orogenic Belt. Journal of the Geological Society, 164, 31-47. https://doi.org/10.1144/0016-76492006-022.

Wood, D. A. (1980). The application of a ThHfTa diagram to problems of tectonomagmatic classification and to establishing the nature of crustal contamination of basaltic lavas of the British Tertiary Volcanic Province. Earth and Planetary Science Letters, 50(1), $11-30$.

Xiao, W., \& Santosh, M. (2014). The western Central Asian Orogenic Belt: a window to accretionary orogenesis and continental growth. Gondwana Research, 25(4), 1429-1444. https://doi.org/10.1016/j. gr.2014.01.008.

Xiao, W. J., Huang, B. C., Han, C. M., Sun, S., \& Li, J. L. (2010). A review of the western part of the Altaids: a key to understanding the architecture of accretionary orogens. Gondwana Research, 18(2-3), 253-273. https://doi.org/10.1016/j.gr.2010.01.007.

Yang, G., Li, Y., Santosh, M., Yang, B., Zhang, B., \& Tong, L. (2013a). Geochronology and geochemistry of basalts from the Karamay ophiolitic mélange in West Junggar (NW China): implications for Devonian-Carboniferous intra-oceanic accretionary tectonics of the southern Altaids. Geological Society of America Bulletin, 125(3-4), 401-419. https://doi.org/10.1130/B30650.1. 
Yang, G., Li, Y., Santosh, M., Yang, B., Zhang, B., \& Tong, L. (2013b). Geochronology and geochemistry of basalts the Karamay ophiolitic mélange in West Junggar (NW China): implications for DevonianCarboniferous intra-oceanic accretionary tectonics of the southern Altaids. Geological Society of America Bulletin, 125(3-4), 410 419. https://doi.org/10.1130/B30650.1.

Yang, G., Li, Y., Tong, L., \& Yang, B. (2015). Oceanic Island Basalts from the Darbut and Karamay Ophiolitic Mélange in West Junggar (NW China): product of a Middle Devonian mantle plume? Acta Geologica Sinica, 89, 105-106. https://doi.org/10.1111/1755-6724. 12308 63.

Yang, G., Li, Y., Tong, L., Wang, Z., Duan, F., Xu, Q., \& Li, H. (2019). An overview of oceanic island basalts in accretionary complexes and seamounts accretion in the western Central Asian Orogenic Belt. Journal of Asian Earth Sciences, 179, 385-398. https://doi. org/10.1016/j.jseaes.2019.04.011.
Yazdi, M. (1999). Late Devonian-Carboniferous conodonts from eastern Iran. Rivista Italiana di Paleontologica e Stratigrafia, 105, 167200.

Ziegler, W., \& Sandberg, C.A. (1984). Palmatolepis based revision of upper part of Standard Late Devonian conodont zonation. In D.L. Clark (Eds.) Conodont biofacies and provincialism, Geological Society of America, 196, 179-194.

Zong, K., Chen, J. Y., Hu, Z., Liu, Y., Li, M., Fan, H. F., \& Meng, Y. N. (2015). In-situ U-Pb dating of uraninite by fs-LA-ICP-MS. Springer-Science China Earth Science, 58(10), 1731-1740. https://doi.org/10.1007/s11430-015-5154-y.

Publisher's note Springer Nature remains neutral with regard to jurisdictional claims in published maps and institutional affiliations. 